Al-Fikra: Jurnal Ilmiah Keislaman, Vol. 7, No. 2, Juli-Desember 2008

\section{KONFIGURASI PEMIKIRAN POLITIK ISLAM IMAM AL-}

HARAMAIN

\section{Irfan Zulfikar}

Fakultas Syariah dan Ilmu Hukum UIN Suska Riau

\section{Abstract}

The Configuration of Islamic Political Thinking of AlHaramain: Iman al-Haramain was a classical thinker who put his political study in his books among others 'Fiqh' Ushul Fiqh and Theology. As a central figure in theology al-Asy'ari and Fiqh al-Syafii persuasion, he was influenced by socio-cultural condition at the time. Besides, he was also very dynamic in using his reasoning towards various political problems. This was supported by his ability in mastering the science of logic (mantiq) and philosophy. In his political thinking Imam al-Haramain looked unique so that he was often in different opinion with other Sunni political thinkers such as Shihab alDin Ahmad Ibn Rabi', Al-Baqillani, Al-Baghdadi, Al-Mawardi, AlGhazali, Ibn Taimiyah and Ibn Khaldun.

Keywords: Configuration, Political thinking, State and Government

\section{Pendahuluan}

Berdasarkan perspektif pemikiran politik Islam Sunni klasik ${ }^{1}$ agama dan politik (negara) ${ }^{2}$ merupakan dua hal yang tidak dapat

${ }^{1}$ Menurut pemikir politik Islam sunni klasik, Islam sebagai agama merupakan sistem nilai yang mencakup segala aspek kehidupan manusia. Ia tidak hanya mengatur hubungan manusia dengan Tuhan, tetapi juga mengatur hubungan manusia dengan sesamanya dan dengan alam lingkungannya. Salah satu ajaran Islam itu adalah berkenaan dengan kehidupan politik. Hal ini juga diakui oleh pemikir politik Islam kontemporer seperti Maulana Abu A'la Maududi. Lihat, Abu A'la Maududi, Islamic Law and Constitution, (Karachi: Islamic Publications LTD, 1960), hlm. 2.

2Diskursus mengenai politik merupakan wacana yang tak pernah lepas dari pembicaraan orang. Topik pembicaraan biasanya senantiasa berkisar seputar masalah negara, sistem pemerintahan, sosok penguasa dan segala sesuatu yang
Irfan Zulfikar, Konfigurasi Pemikiran Politik. Islam Imam al-Haramain

dipisahkan bagaikan saudara kembar yang lahir dari satu ibu (tawamun), bahkan keduanya merupakan satu kesatuan yang bersifat organis. Agama memerlukan negara untuk mengembangkan dirinya, sebaliknya negara menjadikan agama sebagai pembimbing etika dan moral.

Namun demikian, masalah hubungan agama dan politik (negara) dalam Islam ${ }^{3}$ tampaknya merupakan kenyataan sejarah yang tidak ada

berhubungan dengan kekuasaan, atau dalam istilah yang lebih teknis politik adalah upaya untuk mencapai, menjalankan dan mempertahankan kekuasaan. Selanjutnya dalam politik juga dibicarakan berbagai unsur, seperti lembaga yang menjalankan aktivitas pemerintahan, masyarakat sebagai pihak yang berkepentingan, kebijaksanaan dan hukum-hukum yang menjadi sarana pengaturan masyarakat dan cita-cita yang hendak dicapai. Kenyataan ini diakui oleh Maurice Duverger di dalam bukunya Sosiologi Politik. Informasi lebih lanjut lihat pada, Maurice Duverger, Sociologi Politik, (Jakarta: Rajawali, 1985), hlm. V.

${ }^{3}$ Dalam pemikiran politik Islam terdapat, paling tidak, ada tiga paradigma tentang hubungan agama dan negara (daulab). Nuansa diantara ke tiga paradigma in terletak pada konseptualisasi yang diberikan kepada kedua istilah tersebut Paradigma pertama, (memecahkan) masalah dikotomi dengan mengajukan konsep bersatunya agama dan negara. Agama dan negara, dalam hal ini tidak dapa dipisahkan (integrated). Wilayah agama juga meliputi politik dan negara. Karenanya menurut paradigma ini, negara merupakan lembaga politik dan keagamaan sekaligus. Pemerintahan negara dilaksanakan atas dasar "kedaulatan Ilahi" (Devine sovereignty), berdasarkan pada wahyu, karena memang kedaulatan itu berasal dan berada di "tangan" Tuhan. Paradigma seperti ini dianut oleh kelompok Syi'ah. Syi'ah memandang negara adalah lembaga keagamaan yang mempunyai fungsi keagamaan. Menurut Syi'ah, legitimasi keagamaan berasal dari Tuhan dan diturunkan lewat garis keturunan Nabi Muhammad, dengan demikian legitimasi politik harus berdasarkan legitimasi keagamaan dan hal ini hanya dimiliki oleh keturunan Nabi. Paradigma kedua memandang agama dan negara berhubungan secara simbiotik, yaitu berhubungan timbal balik dan saling memerlukan. Dalam hal ini agama memerlukan negara, karena dengan negara agama dapat berkembang. Sebaliknya negara memerlukan agama, karena dengan agama negara dapat berkembang dalam bimbingan etika dan moral. Paradigma ketiga bersifat sekularistik. Paradigma ini menolak baik hubungan integralistik maupun simbiotik antara agama dan negara. Sebagai gantinya paradigma ketiga ini mengajukan pemisahan antara agama dan negara. Dalam konteks Islam paradigma sekularistik menolak pendasaran negara kepada Islam, atau paling tidak menolak determinasi Islam akan bentuk tertentu dari negara. Salah seorang tokoh paradigma ini adalah Ali Abd al-Raziq seorang cendikiawan Muslim dari Mesir. Isu sentral dalam karyanya Al-Islam wa Ushul al-Hukm adalah bahwa Islam tidak mempunyai kaitan 384 
Al-Fikra: Jurnal Ilmiah Keislaman, Vol. 7, No. 2, Juli-Desember 2008 penyelesaiannya secara tuntas dalam al-Qur'an maupun Sunnah Nabi saw. Oleh karena itu, pemahaman dan penafsiran para pemikir politik dan praktisi politik terhadap al-Qur'an maupun Sunnah yang berhubungan dengan politik-pun berbeda-beda pula. ${ }^{4}$

Tanpa disadari telah terbangun kesadaran sejarah yang menjadi sumber munculnya gagasan yang bermacam-macam sehubungan dengan otoritas politik dalam Islam. ${ }^{5}$ Kenyataan ini berkembang

sama sekali dengan sistem pemerintahan kekhalifahan; kekhalifahan, termasuk alkbulafah al-rasyidin, bukanlah sebuah sistem politik keagamaan (keislaman), tetapi sebuah sistem yang duniawi. M. Din Syamsuddin, Etika Agama dalam membangun Masyarakat Madani, (Jakarta: Logos, 2000), hlm. 58-61.

${ }^{4}$ Hubungan antara agama dan politik dalam Islam selalu menjadi topik pembicaraan menarik, baik oleh golongan yang berpegang kuat pada ajaran agama maupun oleh golongan yang berpandangan sekuler. Bagi umat Islam, munculnya topik pembicaraan tersebut berpangkal dari permasalahan: Apakah kerasulan Muhammad SAW. mempunyai kaitan dengan masalah politik: atau apakah Islam merupakan agama yang terkait erat dengan urusan politik, kenegaraan dan pemerintahan; dan apakah sistem dan bentuk pemerintahan, sekaligus prinsipprinsipnya terdapat dalam Islam? Munculnya permasalahan tersebut dipandang wajar, karena risalah Islam yang dibawa Nabi Muhammad saw. adalah agama yang penuh dengan ajaran dan undang-undang (qawanin) yang bertujuan membangun manusia guna memperoleh kebahagiaan hidup di dunia dan di akhirat. Artinya, Islam menekankan terwujudnya keselarasan antara kepentingan duniawi dan ukhrawi. Hal ini juga ditegaskan oleh Imam al-Ghazali di dalam kitabnya Kimya-i Sa'adah, bahwa politik (pemerintahan) dan agama memiliki hubungan yang simbolik. Keduanya punya tujuan yang sama, yakni untuk menciptakan kesejahteraan umat manusia (maslahat-i zandaqani). Selanjutnya Islam menurut Imam al-Ghazali, mengandung ajaran yang integratif antara tauhid, ibadah, akhlak dan moral serta prinsip-prinsip umum tentang kehidupan masyarakat. Lihat pada, Al-Ghazali, Kimya-i Sa'adat, Jilid I, (Teheran: t.p, 1940), hlm. 87.

${ }^{5}$ Selama perjalanan sejarah Islam, negara dan pemerintahan yang pertama terkenal dengan Negara Madinah. Kajian terhadap negara dan pemerintahan in dapat diamati dengan menggunakan dua pendekatan. Pertama, pendekatan normatif Islam yang menekankan pada pelacakan nash-nash al-Qur'an dan Sunnah Nabi yang mengisyaratkan adanya praktek pemerintahan yang dilakukan oleh Nabi dalam rangka siyasah syar'iyah. Kedua, pendekatan deskriptif-historis dengan mengidentikkan tugas-tugas yang dilakukan oleh Nabi di bidang muamalah sebagai tugas-tugas negara dan pemerintahan. Hal ini diukur dari sudut pandang teori-teori politik dan ketatanegaraan. Ditinjau dari dua pendekatan tersebut, diakui oleh sebagian pemikir teori politik Islam bahwa eksistensi negara dan pemerintahan
Irfan Zulfikar, Konfigurasi Pemikiran Politik. Islam Imam al-Haramain

secara berangsur-angsur yang bermula dari eksplorasi dan renungan atas praktik politik dalam Islam masa awal yang selanjutnya mengalami kristalisasi dan membentuk teori-teori politik Islam selanjutnya. ${ }^{6}$

pada masa Rasulullah sudah terbentuk. Terbentuknya negara dan pemerintahan Madinah, hal ini berimplikasi terhadap perkembangan penganut Islam yang menjelma menjadi kelompok sosial dan memiliki kekuatan politik riil pada pasca periode Mekkah di bawah pimpinan Nabi Muhammad saw. Pada awal periode Mekkah pengikut beliau yang jumlahnya relatif kecil belum menjadi suatu komunitas yang mempunyai daerah kekuasaan dan berdaulat. Mereka merupakan golongan minoritas yang lemah dan tertindas, sehingga tidak mampu tampil menjadi kelompok sosial penekan terhadap kelompok sosial mayoritas kota itu yang berada di bawah kekuasaan aristokrat Quraisy, yang masyarakatnya homogen. Tapi setelah di Madinah, posisi Nabi dan umatnya mengalami perubahan besar. Di kota itu, mereka mempunyai kedudukan yang baik dan segera merupakan umat yang kuat dan dapat berdiri sendiri. Nabi sendiri menjadi kepala dalam masyarakat yang baru dibentuk itu dan yang akhirnya merupakan suatu negara. Suatu negara yang daerah kekuasaannya di akhir zaman Nabi meliputi seluruh Semenanjung Arabia dengan kata lain di Madinah Nabi Muhammad bukan lagi hanya mempunyai sifat Rasul, tetapi juga mempunyai sifat Kepala Negara. Kenyataan sejarah ini telah diakui pula oleh beberapa pemikir Barat (orientalis), seperti D.B. Macdonald sebagaimana yang dikutip oleh Muhammad Dhiya' al-Din al-Rayis, di dalam kitabnya Al-Nazhariyat al-Siyasat al-Islamiyat "Di sini (Madinah), telah terbentuk negara Islam pertama dan telah meletakkan dasar-dasar politik bagperundang-undangan Islam". Lihat, Muhammad Dhiya' al-Din al-Rayis, AlNazhariyat al-Siyasat al-Islamiyat, (Mishr: Maktabat al-Anlu, 1957), hlm. 15. Juga diakui oleh Thomas W. Arnold "Negara Madinah itu dalam waktu yang bersamaan Nabi Muhammad adalah sebagai pemimpin Agama dan Kepala Negara". Lihat pada, Thomas W. Arnold, The Caliphate, (London: Routledge and Kegan Paul LTD., 1965), hlm. 30. Orientalis-orientalis lain seperti, H.A.R. Gibb mengatakan bahwa, "Dengan demikian, jelaslah bahwa Islam bukanlah sekedar kepercayaan agama individual, namun ia meniscayakan berdirinya suatu bangunan masyarakat yang independen. Ia mempunyai metode tersendiri dalam sistem kepemerintahan, perundang-undangan, dan institusi. Lihat informasi lanjut pada, H.A.R. Gibb, Mubammadanism An Historical Survey, (London: Oxford University Press, 1949), hlm. 3. Dan orientalis berikutnya R. Strothmann mengatakan, "Islam adalah suatu fenomena agama dan politik karena pembangunnya adalah seorang Nabi, yang juga merupakan seorang politikus yang bijaksana, atau seoranga negarawan.” Lihat pada R. Strothmann, Mobammaed Prophet and Statement, (London: Oxford University, 1961), hlm. 222-223.

${ }^{6}$ Salah satu teori itu, misalnya, menegaskan bahwa pembentukan kekhalifahan merupakan mandat yang dirujukkan sepenuhnya pada masa-masa 
Al-Fikra: Jurnal Ilmiah Keislaman, Vol. 7, No. 2, Juli-Desember 2008

Terhadap kajian dan penulisan teori-teori politik, kelihatannya para pemikir Islam Sunni klasik cenderung menciptakan teori-teori politik sendiri. Teori-teori politik yang mereka hasilkan merupakan bagian dari kajian ilmu fiqh, kalam, tarikh, filsafat, maupun adab (sastra). Bahkan, ada juga yang termaktub dalam kajian tafsir-tafsir alQur'an dan syarah (penjelasan) atas hadis-hadis. ${ }^{7}$

Oleh karena itu, teori-teori pemikiran Islam Sunni klasik meskipun banyak dipengaruhi oleh suatu sifat tertentu dan tampil dalam wajah tersendiri, serta perkembangannya berhenti pada titik tertentu, namun hasil tersebut merupakan kekayaan ilmiah yang sangat bernilai dan harus diperhatikan serta dikaji lebih lanjut.

Sepanjang penelitian yang ada, sarjana Islam pertama yang menuangkan gagasan atau teori politiknya dalam suatu karya ilmiyah

awal Islam, disamping al-Qur'an dan Sunnah Nabi. Kepemimpinan itu tidak bersifat kolektif tapi atas otoritas suatu badan yang disebut abl al-halli wa al-'aqd. Laki-laki Muslim yang saleh, punya kompetensi, dan memiliki garis keturunan Quraisy. Harus menegakkan hukum Islam (syari'ah) tapi tidak bisa dikudeta sekalipun melanggar perjanjian mandat. Munculnya teori-teori politik dalam Islam semakin mengingatkan kita pada metode kritik nalar Islam-nya Mohammed Arkoun yang menyatakan bahwa tumpukan pemikiran Islam ibarat lapisan-lapisan geologis pada bumi. Kita, generasi Islam yang hidup di millinium ketiga ini, semakin terhalang untuk menembus peristiwa pembentukan pertama (al-hadats al ta'sisiyu al-awwal) menuju peristiwa pembangun awal, yang sebetulnya masih segar dan kaya. Para pemikir Islam telah "memperkosa" al-Qur'an dengan tujuan-tujuan membangun teks-teks lain yang dapat memenuhi kebutuhan dan selera suatu masa tertentu. Celakanya dalam memahami karya intelektual Islam klasik, kita sering mengabaikan lingkup budaya yang melatarinya dan konteks sosial atau aliran teologi yang menjadi payungnya. Lihat pada, Ulumul Qur'an, No. 5 dan 6 , Vol. V. Th. 1994, Metode Kritik. Akal Islam : Wawancara dengan Mohammed Arkoun.

${ }^{7}$ Ilmu politik Islam tidak dikembangkan sebagai satu disiplin akademik yang independen, tapi ia berkembang sebagai bagian dari yurisprudensi Islam dengan determinasi dominasi negara sebagai landasan konsistensi pelaksanaan syari’ah. Karena itu, ketika pintu ijtihad ditutup pada abad ke-13 bersamaan dengan kejatuhan Dinasti Abbasiyah, para pemikir politik Islam tidak dapa mengembangkan teori-teori baru sehubungan dengan persoalan-persoalan politik Islam. Baca selengkapnya pada, Masudul Hasan, Reconstruktion of Political Thought in Islam, (Pakistan : Islamic Publication (Pvt) Ltd., 1988), hlm. 15.
Irfan Zulfikar, Konfigurasi Pemikiran Politik Islam Imam al-Haramain

adalah Syihab al-Din Ahmad Ibn Rabi'. ${ }^{8}$ Namun demikian, masih banyak pemikir-pemikir politik Islam lainnya sebelum maupun sesudah Syihab al-Din Ahmad Ibn Rabi', seperti, Al-Baqillani, ${ }^{9}$ AlBaghdadi, ${ }^{10}$ Al-Mawardi, ${ }^{11}$ Al-Haramain (Al-Juwaini), ${ }^{12}$ Al-Ghazali, ${ }^{13}$ Ibn Taimiyah ${ }^{14}$ dan Ibn Khaldun, ${ }^{15}$ serta banyak pemikir-pemikir politik Islam yang lain.

${ }^{8} \mathrm{Nama}$ lengkap beliau adalah Syihab al-Din Ahmad bin Muhammad bin Abi Rabi'. Beliau hidup pada masa pemerintahan Khalifah Al-Mu'tashim (833-842 M.) Dinasti Abbasiyah. Pemikiran politiknya termuat dalam bukunya Suluk al-Malik, fi Tadbir al-Mamalik. Lihat, Muhammad Jalal Syaraf dan Ali Abd al-Mu'thi Muhammad, Al-Fikr al-Siyasah fi al-Islam, (Iskandariyat : Dar al-Jami'at al-Mishriyat, 1978), hlm. 13.

${ }^{9}$ Nama lengkap beliau Abu Bakar Muhammad bin al-Thayyib bin Muhammad bin Ja'far al-Qasim al-Baqillani (w. 403 H/1013 M). Teori politiknya terdapat dalam bukunya yang berjudul : Al-Tambid fi al-Radd 'ala al-Mulhidat wa alKhawarij wa al-Mu'tarilah. Ann K.S. Lambton, State and Government in Medieval Islam, (London: Oxford University Press, 1981), hlm. 70.

${ }^{10}$ Nama lengkapnya Abu Mansur Abd al-Qadir bin Thahir al-Baghdadi (w.429 H/1037 M.). Mengenai Formulasi doktrin politiknya disisipkan dalam karyanya yang berjudul : Ushu al-Din. Lihat, M.TH. Houstma, First Encyclopaedia of Islam, Jilid II, (Leiden : E.J. Brill, 1987), hlm. 570.

${ }^{11}$ Nama lengkapnya Abu al-Hasan Ali bin Muhammad bin Habib al-Bashri al-Baghdadi al-Mawardi (367-450 H./974-1058 M.). Karyanya yang terkenal di bidang politik dan tata negara adalah Al-Abkam al-Sulthaniyat. Lihat Ibid., hlm. 289.

${ }^{12} \mathrm{Nama}$ lengkapnya Abu al-Ma'ali Abd al-Malik bin Abdullah bin Yusuf bin Muhammad bin Hayyawaih al-Sinbisi al-Juwaini (419-478 H./1028-1087 M.) Beliau dikenal juga dengan sebutan Imam al-Haramain (Imam Dua Tanah Haram/suci), karena selama empat tahun ia menjadi Imam di Mekkah dan Madinah (keduanya tanah haram/suci). Pembahasannya tentang Imamah dan siyasah disisipkan dalam karya teologinya : Kitab al-Irsyad ila Qawathi'i al-Adillat fi Ushul al-I'tiqad, dan Lam'u al-Adillat fi Qawaid al-'Aqaid al-Sunnat wa al-Jama'at. Lihat Ibid., hlm. 10.

${ }^{13}$ Nama lengkapnya Abu Hamid Muhammad al-Ghazali (450-505 H./10581111M.). Teori politik terdapat dalam kitabnya : Ibya 'Ulum al-Din, Al-Iqtishad wa alI'tiqad, dan Al-Tibr al-Masbuke fi Nashibat al-Muluk. Lihat, Ibid. 107.

${ }^{14}$ Nama lengkapnya Taqiyuddin Abu al-Abbas bin Taimiyah (661-728 H./1262-1328 M.). Gagasan maupun teori politiknya terdapat dalam karyanya : Al Siyasat al-Syari'at, dan Minhaj al-Sunnat. Lihat Ann K.S. Lambton, State and..., hlm. 143. 
A1-Fikra: Jurnal Ilmiah Keislaman, Vol. 7, No. 2, Juli-Desember 2008

Imam Al-Haramain sebagai sosok tokoh ulama yang fenomenal merupakan tokoh pemikir politik Islam Sunni abad klasik. Beliau lahir di sebuah desa kecil bernama Bustanikan, Naisabur, Persia (419-478 H./1028-1085 M). Imam al-Haramain hidup pada masa pemerintahan dinasti Abbasiyah yang ketika itu sebagai Perdana Menteri adalah Nizham al-Mulk. ${ }^{16}$

Sebagai seorang ulama Sunni, Imam al-Haramain mengikuti mazhab Syafi'i dalam bidang fiqh dan ushul fiqh. Sekalipun dalam bidang fiqh dan ushul fiqh beliau menganut mazhab Syafi'i dan dikenal sebagai tokoh utama dalam mazhab Syafi'i, namun tidak sedikit pendapat beliau yang tidak sejalan dan kontroversi dengan fiqh dan ushul fiqh Syafi'i, seperti dapat dilihat di dalam kitabnya Al-Burban fi Ushul al-Fiqh yang dipandang sebagai kitab kedua bagi kalangan mazhab Syafi'i setelah kitab Al-Risalah.

Di bidang ilmu kalam, beliau dikenal sebagai seorang penganut aliran Asy'ariyah moderat, banyak pendapatnya yang berseberangan dengan tokoh pendiri aliran tersebut. Sebagai tokoh kalam, ia termasuk generasi ketiga dalam urutan imam-imam besar aliran Asy'ariyah, yaitu setelah Abu Hasan al-Asy'ari dan al-Qadi al-Baqillani Sebagaimana di dalam ilmu fiqh dan ushul fiqh ia berbeda pendapat dengan Imam Syafi'i, di dalam ilmu kalam ia juga berbeda pendapat dengan Imam al-Asy'ari, terutama di dalam menentukan posisi akal untuk menyelesaikan masalah-masalah yang berhubungan dengan perbuatan manusia. ${ }^{17}$

Imam al-Haramain termasuk salah seorang ulama yang produktif dalam melahirkan karya-karya tulisnya yang monumental. Baik bidang fiqh seperti, Nibayah al-Matlab fi al-Fiqh, Mugis al-Kbulq fi Tarjih Mazhab al-Syafii dan kitab fiqh lainnya, bidang ketatanegaraan

${ }^{15 N a m a}$ lengkapnya Abd al-Rahman bin Khaldun (732-808 H./1332-1406). Pemikiran politiknya beliau termuat di dalam karyanya yang terkenal : Muqaddimah. Lihat, Muhammad Jalal Syaraf dan Ali Abd al-Mu'thi' Muhammad, Al-Fikr alSiyasi..., hlm. 486. hlm. 17.

${ }^{16}$ Abd al-'Azim al-Dib, Imam al-Haramain, (Kuwait: Dar al-Qalam, 1981),

${ }^{17}$ Ibid., hlm. 50. Lihat juga pada Dewan Redaksi, Ensiklopedi Islam, Jilid II, (Jakarta : Ichtiar Baru van Hoeve, 1994), hlm. 328.
Irfan Zulfikar, Konfigurasi Pemikiran Politik. Islam Imam al-Haramain

Giyas al-Umam fi Iltiyas al-Zulam, bidang ushul fiqh beliau menulis kitab seperti, Al-Burhan fi Ushul al-Figh, Al-Waraqat, Al-Tubfah dan kitab ushul fiqh lainnya. Selanjutnya karya beliau dalam bidang teologi di antaranya seperti, Kitab al-Irsyad ila Qawathi'i al-Adillat fi Ushul al-I'tiqad, Lam'u al-Adillat fi Qawaid al-'Aqaid al-Sunnat wa al-Jama'at (kedua kitab ini beliau sisipkan tentang persoalan Imamah dan siyasah atau politik Islam), dan kitab teologi lainnya. Karya-karya tulis beliau hingga kini menjadi kajian khusus diberbagai perguruan tinggi Islam di Timur Tengah. ${ }^{18}$

Imam al-Haramain ide dan gagasannya dalam bidang politik cukup menarik. Sehingga tidak jarang pemikiran-pemikiran politik beliau kontradiktif dengan pemikir-pemikir politik Islam Sunni klasik lainnya. Salah satu pemikiran politik beliau yang kontradiktif dengan ulama Sunni klasik lainnya adalah tentang dasar hukum pembentukan lembaga pemerintahan (imamah-khilafah). Mengenai fungsi keberadaan lembaga pemerintahan dan dasar otoritas mendirikannya, Imam al-Haramain nampaknya berseberangan dengan pendapatpendapat ulama klasik lain seperti al-Baghdadi dan al-Mawardi. Kedua ulama belakangan ini berpendapat bahwa, dasar hukum lembaga pemerintahan (imamah-khilafah), wajib berdasarkan ijma' dan atas dasar nash atau perintah wahyu. ${ }^{19}$ Sebaliknya Imam al-Haramain berpendapat bahwa dasar hukum pembentukan lembaga pemerintahan wajib hanya berdasarkan atas ijma', dan bukan atas dasar nash atau perintah wahyu. ${ }^{20}$

Pendapat Imam al-Haramain tersebut berkaitan dengan pandangannya tentang hakikat imamah. Beliau mengatakan : "masalah

${ }^{18}$ Abdul Aziz Dahlan, dkk., Ensiklopedi Hukum Islam, Jilid III, Jakarta : Ichtiar Baru van Hoeve, 1996), hlm. 839.

${ }^{19}$ Komentar Al-Baghdadi tentang eksistensi lembaga pemerintahan, dapat dilihat pada, Ann. K.S Lambton, State and..... hlm. 73-77. Selanjutnya Argumentasi Al-Mawardi tentang eksistensi lembaga pemerintahan dapat dilihat, Al-Mawardi, Al-Abkam al-Sulthaniyat, (Beirut: Dar al-Fikr, tt.), hlm. 3-5.

${ }^{20}$ Imam al-Haramain, Lam'u al-'Adillat fi Qawa'id Abl al-Sunnab wa al Jama'ah, Tahqiq Fauqiyah Husain Mahmud, Tahqiq ulang Mahmud al-Khudairiy, (Kairo Dar al-Mishriyyat, 1965), hlm. 71. (Selanjutnya dibaca Imam al-Haramain, Lam'u al-'Adillat). 
Al-Fikra: Jurnal Ilmiah Keislaman, Vol. 7, No. 2, Juli-Desember 2008

imamah tidak termasuk dalam prinsip-prinsip al-i'tiqad (keyakinan). ${ }^{21}$ Orang yang tidak mengetahui asal atau sumber imamah itu menimbulkan dua hal. Pertama, cenderung menjadi ta'asshub (fanatik) dan melanggar kebenaran. Kedua, hal itu menjadi lapangan ijtihad yang serba mungkin dan boleh jadi (al-mujtahadat al-mubtamalat). Di dalamnya tidak terdapat dalil-dalil yang qath'iy (pasti). Argumentasi Imam al-Haramain ini berkaitan dengan penolakannya terhadap Syi'ah sekte Imamiyah yang berpendapat bahwa pemangku imamah telah ditetapkan oleh Nabi kepada Ali sebagai penggantinya. Juga untuk menolak bahwa nash penetapan itu dilakukan secara rahasia. ${ }^{22}$ Di sini jelas bahwa, Imam al-Haramain tampak berpikir realistis yang memperhitungkan keadaan sosial-politik umat Islam ketika itu.

Berangkat dari wacana di atas, penulis merasa tertarik untuk meneliti dan mengkaji secara mendalam dan komprehensif terhadap pemikiran Imam al-Haramain tentang sistem pemerintahan Islam dalam sebuah tulisan ilmiah ini. Hal ini berdasarkan, bahwa persoalan politik memiliki kajian dari berbagai dimensi dan varian. Oleh sebab itu, agar kajian penelitian ini lebih apresiatif dan komprehensif, penulis memfokuskan kepada pemikiran politik Imam al-Haramain tentang sistem pemerintahan Islam. Bagaimana pemikiran Imam Al-Haramain tentang sistem pemerintahan Islam dan bagaimana pula sistem pemerintahan Islam yang ideal menurut pandangannya? Pandanganpandangannya ini akan dikaji melalui karya-karyanya yang monumental secara tajam, kritis dan analisis.

\section{Dasar Hukum Pembentukan Lembaga Pemerintahan (Imamah- Khilafah)}

${ }^{21}$ Imam al-Haramain, Al-Irsyad ila Qawathi'i al-'Adillat fi Ushul al-I'tiqad, Tahqiq Muhammad Yusuf Musa dan 'Ali Abd al-Mun'im Abd al-Hamid, (Mesir : Maktabah al-Khaniji, 1959), hlm. 410. (Selanjutnya dibaca Imam al-Haramain, AlIrsyad).

${ }^{22}$ Ann K.S. Lambton, State and..., hlm. 105
Irfan Zulfikar, Konfigurasi Pemikiran Politik Islam Imam al-Haramain

Lembaga pemerintahan atau negara (imamah ${ }^{23}-k_{\text {khilafah }}{ }^{24}$ ) adalah kepemimpinan umum bagi umat Islam dalam urusan agama dan urusan dunia sebagai pengganti fungsi Nabi saw. Dalam menetapkan lembaga pemerintahan (imamah-khilafah) ini, Sunni, Syi'ah dan Mu'tazilah mempunyai dasar hukum yang berbeda sesuai dengan doktrin yang dianut oleh setiap aliran tersebut. ${ }^{25}$

Imam al-Haramain al-Juwaini berpendapat, bahwa pembentukan lembaga pemerintahan (Imamah-khilafah) hukumnya adalah wajib. Namun demikian, menurut Imam al-Haramain kewajibannya hanya

${ }^{23}$ Menurut pendapat para ahli politik Islam, bahwa aliran Syi'ah adalah Muslim pertama yang melahirkan teori tentang Imamah. Mereka berpendapat bahwa Imamah tidak hanya merupakan suatu sistem pemerintahan, tetapi juga rancangan Tuhan, suatu kepercayaan yang dianggap sebagai penegas keimanan. Buku-buku dogmatik Syi'ah nyaris secara konsisten mengulang-ulang pernyataan tentang pentingnya Imamah yang absolut dengan bersandar pada hadis kontroversial yang menyebutkan, "Siapa pun meninggal dunia tanpa mengenal Imamah yang benar pada masanya berarti ia mati sebagai orang yang tidak beriman." Dikutip dari Abdullah A. Al-Munifi, The Islamic Constitusional Theory", (Disertasi Doktor yang tidak dipublikasikan, Universitas Virginia, 1973), hlm. 119.

${ }^{24}$ Secara etimologis, kata kekhalifahan (khilafah) berarti "menggantikan seseorang". Tetapi, dalam semboyan politik Islam Sunni, kata itu merujuk pada wewenang seseorang yang berfungsi sebagai pengganti Nabi dalam kapasitasnya sebagai pemimpin masyarakat, namun bukan dalam fungsi kenabiannya. Kata Imam juga pernah digunakan para penulis Muslim dengan arti serupa kecual golongan Syi'ah yang memakainya dalam arti yang khusus. Dalam kajian ini, kata "Imam" dan "Khalifah" (dan asal katanya, yakni Imamah dan Khilafah) dapat digunakan secara timbal balik, kecuali yang memerlukan penjelasan khusus. Kata Imamah biasanya merujuk pada negara Islam dalam arti yang umum dan dianggap mencerminkan masa pemerintahan Nabi dan sesudahnya. Namun ada juga yang mengajukan pendapat bahwa istilah itu secara tegas merupakan gambaran periode kedua. Sedang mereka yang dianggap mengembangkan teori Sunni tentang kekhalifahan nyaris selalu mengemukakan istilah tersebut sebagai cermin pemerintahan Islam pasca Nabi. Dikutip dari Ahmed Manzooruddin, The Classical Muslim State", Islamic Studies I, (1962), hlm. 23; dan Qomaruddin Khan, The Political Thought of Ibn Taimiyah, (Islamabad : Islamic Research Institute, 1973), hlm. 141.

${ }^{25}$ Sudirman M. Johan, Politik Keagamaan Dalam Islam (Studi tentang Teori Imamat Mu'tazilat Menurut Konsepsi Abd al-Jabbar serta Perbandingannya dengan Teor Imamat Sunni dan Syi'ab), (Pekanbaru: Susqa Press, 1995), hlm. 106. 
Al-Fikra: Jurnal Ilmiah Keislaman, Vol. 7, No. 2, Juli-Desember 2008

berdasarkan atas ijma', dan bukan atas dasar nash atau perintah wahyu. $^{26}$

Imam al-Haramain dalam menetapkan dasar hukum pembentukan lembaga pemerintahan (Imamah-khilfah) tersebut, berkaitan dengan pandangannya tentang hakikat Imamah itu sendiri. Imam al-Haramain mengatakan bahwa "masalah imamah tidak termasuk dalam prinsip-prinsip al-i'tiqad (keyakinan)."27 Orang yang tidak mengetahui asal atau sumber munculnya imamah itu menimbulkan dua hal. Pertama, cenderung menjadi ta'asshub (fanatik) dan melanggar kebenaran. Kedua, hal itu menjadi lapangan ijtihad yang serba mungkin dan boleh jadi (al-mujtahadat al-mubtamalat). Di dalamnya tidak terdapat dalil-dalil yang qath'iy (pasti). ${ }^{28} \mathrm{Hal}$ ini berkaitan dengan penolakkannya terhadap Syi'ah sekte Imamiyah yang berpendapat bahwa pemangku imamah telah ditetapkan oleh Nabi kepada Ali sebagai penggantinya. Juga untuk menolak bahwa nash penetapan itu dilakukan secara rahasia. Untuk mengetahui kebenaran klaim Syi'ah itu, Imam al-Haramain mengapresiasi tingkat kualitas dan validitas khabar (informasi) atau nash penetapan itu dengan merinci tingkatan-tingkatannya dari berbagai segi. Setiap khabar, kata Imam al-Haramain, mengandung kebenaran atau kebohongan. Ada khabar yang benar dengan argumen atau bukti yang kuat dan pasti. Ada pula khabar dusta dengan dalil atau bukti yang kuat dan pasti. Khabar yang benar ada yang diriwayatkan oleh orang yang punya pengetahuan tentang yang dikhabarkannya itu. Ada pula khabar yang diriwayatkan oleh orang yang tidak punya pengetahuan tentang yang dikhabarkannya itu. Periwayatan khabar oleh orang yang berpengetahuan terhadap yang dikhabarkannya itu, nilainya lebih tinggi. Kemudian masalah ini ia kaitkan dengan tingkatan khabar dalam ilmu hadis, yaitu khabar al-ahad (berita perorangan) yang kebenarannya diragukan, tidak bisa memberikan faedah kebenaran (ilmu). Khabar Mutawatir (berita orang banyak dari orang banyak dan seterusnya) yang dikhabarkan oleh mereka yang punya pengetahuan

${ }^{26}$ Imam al-Haramain, Lam'u al-Adillat...,hlm. 71

${ }^{27}$ Imam al-Haramain, Al-Irsyad...,hlm. 410.

${ }^{28} \mathrm{Ibid}$.
Irfan Zulfikar, Konfigurasi Pemikiran Politik. Islam Imam al-Haramain

terhadap apa yang mereka khabarkan. Tingkatan khabar semacam ini mengandung kebenaran atau ketetapan (ilmu). Sedangkan khabar yang ahad tidak bisa diterima kebenarannya kecuali ada sesuatu yang menguatkan kebenarannya, seperti dapat diterima akal, atau dikuatkan oleh mukjizat, dan atau umat sepakat menerimanya sebagai suatu yang benar. $^{29}$

Karena itu nash yang dinukil oleh Syi'ah tentang penunjukkan Ali oleh Nabi sebagai penggantinya memangku jabatan imam tidak mencapai tingkat mutawatir, melainkan tingkat ahad. ${ }^{30}$ Artinya klaim mereka itu tidak punya otoritas kebenaran, karenanya secara pasti ia batal. Apalagi masalah itu sedemikian penting, maka tidak mungkin Rasul secara sembunyi memberikan ketetapan itu kepada Ali sebagaimana ia tidak menyembunyikan keputusannya mengutus Mu'adz ke Yaman menjadi pemimpin di sana dan sahabat-sahabat lain memimpin peperangan. Demikian juga Abu Bakar tidak secara rahasia menunjuk Umar untuk menjadi penggantinya. Umar pun tidak sembunyi-sembunyi membentuk anggota badan musyawarah yang bertugas memilih seorang dari mereka menjadi khalifah sesudahnya. Seandainya nash itu ada, sebagai yang diberitakan oleh orang-orang Syi'ah, maka tidaklah akan terjadi perbedaan pendapat dipertemuan Tsaqifah itu. Jika mereka mengklaim bahwa nash itu diberikan secara rahasia, maka tidak ada cara kita, kata Imam al-Haramain, untuk mengetahuinya. ${ }^{31}$ Barangkali ia ingin mengatakan, bagaimana kita bisa menerima kebenaran sesuatu yang sifatnya rahasia dan itu tidak termasuk bidang i’tiqad. Sedangkan yang nyata saja masih memerlukan dalil untuk membuktikan kebenarannya.

$$
\text { Dengan argumen-argumen itu, Imam al-Haramain }
$$
berkesimpulan bahwa, tidak ada nash dari Nabi yang menetapkan seseorang untuk menjadi imam atau khalifah sesudahnya. ${ }^{32}$ Jadi pembentukan imamah berdasarkan ijma' bukan karena pertimbangan nash. Ijma' dalam pemikirannya adalah kesepakatan ulama seluruh

${ }^{29}$ ibid., hlm. 411-417.

30Ibid., 419.

${ }^{31}$ Ibid., hlm. 420-421.

${ }^{32}$ Imam al-Haramain, Lam'u al-Adillat...,hlm. 71. 
A1-Fikra: Jurnal Ilmiah Keislaman, Vol. 7, No. 2, Juli-Desember 2008

umat tentang hukum yang berkesesuaian dengan kebiasaan. ${ }^{33}$ Pendapat ini berbeda dari konsep ijma' menurut ulama pendahulunya, yaitu kesepakatan seluruh umat. Menurut penulis, Imam al-Haramain tampak berpikir realistis yang memperhitungkan keadaan sosial politik umat Islam saat itu. Sebab, Islam telah dianut oleh berbagai suku bangsa dan mendiami wilayah yang luas, melintasi tiga benua, disintegrasi politik telah melanda daulah Abbasiyah ketika itu, gerakan politik Syi'ah dan aliran-aliran keagamaan telah timbul, sehingga dengan keadaan itu sulit mencari konsensus seluruh masyarakat Islam.

Lebih lanjut Imam al-Haramain menjelaskan, jika mereka mendasarkan klaim mereka pada hadis berikut :

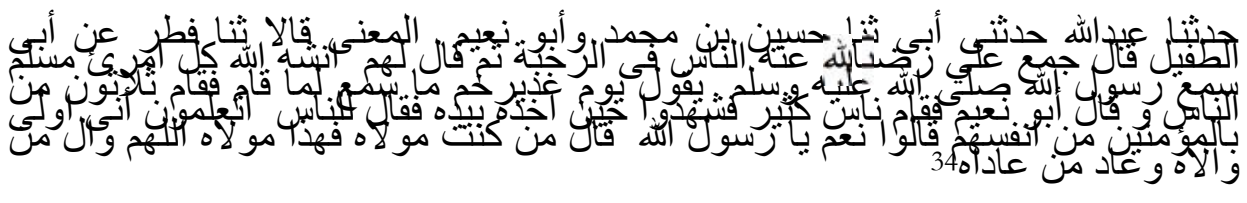

Menurut Imam al-Haramain, hadis di atas belum bisa mengukuhkan pendapat mereka. Sebab, hadis di atas termasuk khabar ahad dan kandungan maknanya tidak bersifat khusus yang berlaku sesudah wafatnya Nabi. ${ }^{35}$

Setelah Imam al-Haramain menilai kualitas pemberitaan nash penetapan itu, kandungan hadis itu berkaitan dengan sebab khusus sesuai dengan kenyataan sejarah, dan nash itu tidak menunjukkan secara tegas pengangkatan terhadap Ali sebagai pengganti Nabi, ${ }^{36}$

33Imam al-Haramain, Al-Irsyad...,hlm. 418.

${ }^{34}$ Ahmad ibn Hanbal, Al-Musnad, Jilid IV, (Beirut : Dar al-Fikr, tth.), hlm. 119 dan 370.

${ }^{35}$ Ibid., hlm. 421-422.

${ }^{36}$ Berkenaan dengan hadis di atas ulama Sunni yang lain berbeda dengan Imam al-Haramain tentang kualitas hadis tersebut. Ulama Sunni yang lain menganggap bahwa hadis Khadir Khum adalah hadis palsu yang tidak dapat dijadikan dasar hukum dalam penentuan khalifah atau imam. Dengan dasar pertimbangan hadis Khadir Khum adalah dha'if, karena diriwayatkan oleh orang yang tidak dapat dipercaya kebenarannya, tidak dhabit dan ittisal. Lihat Ibn Abi alHadid, Syarb Nahj al-Balaghat, I (ed) Muhammad Abu Fahdl Ibrahim, (Kairo : ttp., 1959), hlm. 135. Dikutip dari Sudirman M. Johan, op.cit., hlm. 119.
Irfan Zulfikar, Konfigurasi Pemikiran Politik. Islam Imam al-Haramain

maka klaim mereka itu, kata Imam al-Haramain, gugur. Jika nash tentang Imamah sudah gugur maka dasar otoritas dan pertimbangan bagi penegakkan Imamah itu tidak ada jalan lain kecuali dengan al ikhtiyar (pemilihan). Cara ini telah berjalan sepanjang masa dan tidak ada yang menentang prinsip pemilihan dalam pengangkatan khalifah. Sedangkan dalilnya ijma'. ${ }^{37}$

Di sini Imam al-Haramain berbeda dari ulama sunni lain (akan datang penulis jelaskan) yang berpendapat bahwa penegakkan Imamah itu di samping ijma' juga atas dasar pertimbangan syara' (wajib syar'i) dan perintah wahyu. Tapi ia menyetujui pendapat bahwa imamah diperlukan untuk melindungi agama dan mengatur kepentingan masyarakat.

Yang berbeda pendapat dengan Imam al-Haramain, antara lain adalah al-Baghdadi, ia mengakui bahwa umat Islam dalam hal pembentukan lembaga pemerintahan (Imamah-khilafah) ini memang telah terjadi perselihan. Yaitu golongan yang mengharuskan (mewajibkan) dan ada pula yang membolehkan (tidak wajib). Golongan yang mengharuskan atau yang mewajibkan ada dua pendapat, wajib karena wahyu dan ijma' dan wajib karena pertimbangan akal. Dan beliau sendiri memilih bahwa kewajibannya itu adalah atas dasar wahyu dan perintah nash. Al-Baghdadi dalam hal ini sependapat dengan Asy'ari bahwa keharusan itu berdasarkan nash atau perintah wahyu. Pendapat Ini diperkuat oleh al-Baghdadi dengan keputusan para sahabat Nabi yang sepakat membentuk pemerintahan segera setelah wafatnya Nabi. Lagi pula syari'at Islam mengandung seperangkat hukum, yang pelaksanaannya membutuhkan suatu organisasi dan seorang imam yang memimpinnya. ${ }^{38}$

Imam Mawardi salah seorang ulama sunni mengetengahi di antara dua pendapat di atas. Al-Mawardi memahami bahwa, Imamahkhilafah (pemerintahan atau kepemimpinan) dijabat oleh khalifah, atau pemimpin (al-rais), atau raja (Al-mulk), atau penguasa (al-sulthan), atau kepala negara (qaid al-daulat), dan kepadanya ia berikan label agama. ${ }^{39}$

${ }^{37}$ Ibid., hlm. 423

${ }^{38}$ Ibid., hlm. 77.

${ }^{39}$ Muhammad Jalal Syaraf, Al-Fiker al-Siyasi...,hal. 297. 
Al-Fikra: Jurnal Ilmiah Keislaman, Vol. 7, No. 2, Juli-Desember 2008

Hal ini tampak dalam pendahuluan kitabnya Al-Ahkam al-Sulthaniyat. "Sesungguhnya Allah menjadikan bagi umat seorang pemimpin untuk menggantikan fungsi Nabi (al-nubuwwat, kenabian) untuk menlindungi agama, dan Dia (Allah) mempercayakan kepadanya (Nabi) memegang kekuasaan politik untuk mengelola urusan agama yang disyari'atkan dan mengatur terwujudnya kemaslahatan umat."40 Maka al-Mawardi menyatakan bahwa "Imamah dibentuk untuk menggantikan fungsi kenabian guna memelihara agama dan mengatur dunia." 41 Pernyataan ini mengandung arti bahwa, seorang imam adalah pemimpin agama di satu pihak dan pemimpin politik di pihak lain, demikian komentar Muhammad Jalal Syaraf dan Ali Abd al-Mu'thiy Muhammad. ${ }^{42}$ Sifat kepemimpinan ini pula yang tampak dalam diri Muhammad saw. sebagai Rasul Allah di satu pihak dan sebagai pemimpin masyarakat atau kepala negara di pihak lain. Demikian juga dalam diri Khulafaurrasyidin, mereka memegang kepemimpinan agama dan kepemimpinan politik sekaligus.

Dasar pembentukan imamah itu, kata al-Mawardi, bagi umat wajib secara ijma'. Ia membenarkan hal ini diperselisihkan. Apakah menjadi wajib karena pertimbangan akal atau berdasarkan hukum agama (bi al-syar'i). Menurutnya ada dua golongan, pertama, wajib karena pertimbangan akal. Alasannya manusia itu adalah makhluk sosial. Dalam berhubungan dan pergaulan di antara mereka mungkin terjadi perselisihan, permusuhan dan penganiayaan. Karenanya diperlukan seorang pemimpin yang akan mencegah kemungkinankemungkinan itu. Jadi secara logika manusia membutuhkan pemerintahan. Seandainya tidak ada para penguasa niscaya masyarakat menjadi kacau balau dan mereka menjadi perusak. Golongan kedua, berpendapat, kewajiban adanya imamah berdasarkan hukum agama (bi al-syar'i) bukan karena pertimbangan akal. Karena eksistensi Imamah untuk melaksanakan syari'at. Dengan menfungsikan akal memang dapat mencegah setiap orang tidak melakukan penganiayaan dan berlaku adil dalam segala tindakannya. Akan tetapi hukum agama

${ }^{40}$ Al-Mawardi, Ahkam..., hlm. 3.

${ }^{41}$ Ibid., hlm. 5.

${ }^{42}$ Muhammad Jalal Syaraf, Al-Fiker al-Islami..., hlm. 297
Irfan Zulfikar, Konfigurasi Pemikiran Politik Islam Imam al-Haramain menyerahkan segala urusan kepada pemegang kekuasaan dalam urusan agama. Allah menyatakan :

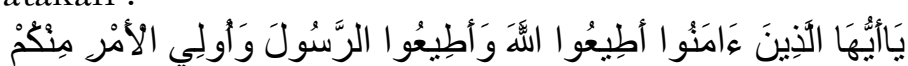

Artinya : "Hai orang-orang yang beriman taatlah kepada Allah dan taatlah kepada Rasul dan kepada pemimpin kamu”. (Q.S. al-Nisa' : 59). ${ }^{43}$

Dengan demikian Allah mewajibkan kepada umat agar mentaati ulul amri (pemegang kekuasaan), yaitu para pemimpin (al-aimmat), yang menjadi penguasa umat. Hal ini berdasarkan hadis Rasulullah saw. yang diriwayatkan oleh Hisyam bin 'Urwah dari Abi Shaleh dari Abu Hurairah Rasulullah bersabda :

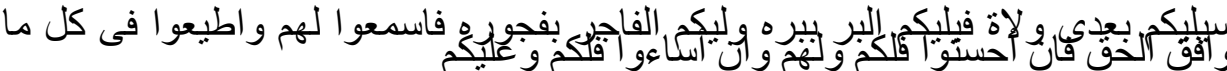

Artinya : "Yang akan memerintah kamu sesudabku adalah para penguasa, penguasa yang baik akan memerintah kamu dengan kebaikan dan penguasa yang jahat akan memerintah kamu dengan kejahatannya, maka dengarkan dan taatilah segala yang sesuai dengan kebenaran. Jika mereka berbuat baik maka itu untuk kamu dan mereka, tapi jika mereka berbuat jahat maka akibatnya untuk kamu dan mereka bertanggung jawab atasnya". 44

Apabila penetapan hukum adanya imamah itu adalah wajib, maka wajibnya itu, menurut al-Mawardi, adalah fardhu kifayah (kewajiban atau tanggung jawab seluruh umat). Seperti kewajiban melakukan jihad dan menuntut ilmu. Jika ada di antara anggota masyarakat yang melakukannya maka gugurlah kewajiban itu dari seluruh anggota masyarakat. 128

${ }^{43}$ DEPAG RI., Al-Qur'an dan Terjemahnya, (Surabaya : Mahkota, 1989), hlm.

${ }^{44}$ Dikutip dari Al-Mawardi, Abkam..., hlm. 5. Hadis ini kualitasnya dha'if. Diriwayatkan oleh Thabrani dalam kitab Al-Ausath (Majma' al-Bahraini, hlm. 219), dari Abu Hurairah. Al-Haitsami berkata dalam Majma' Zaawaid, jilid V hlm. 218. Bahwa dalam sanad hadis itu terdapat Abdullah bin Muhammad bin Yahya bin Urwah, ia adalah perawi yang dha'if jiddan (lemah sekali). Thabrani berkata bahwa yang meriwayatkan dari Hisyam hanya Abdullah saja dan Hisyam hanya meriwayatkan hadis ini saja dari Abi Shaleh. 
Al-Fikra: Jurnal Ilmiah Keislaman, Vol. 7, No. 2, Juli-Desember 2008

Sebagaimana al-Mawardi, al-Ghazali juga berpendapat bahwa pembentukkan khilafah adalah wajib syar'i. Dasarnya ijma' umat, dan kategori wajibnya fardhu kifayah. ${ }^{45}$ Ijma' umat itu, menurut al-Ghazali, terdapat dalam historis umat Islam. Yaitu terjadinya ijma' para sahabat mengangkat seorang khalifah menggantikan Nabi Muhammad saw. segera setelah beliau wafat. Sejak peristiwa itu sampai pada masa alGhazali, umat Islam selalu berada di bawah pemerintahan sistem khalifah. Artinya selama beberapa abad, umat Islam ijma'46 menerima sistem pemerintahan itu. Jadi konsep ijma' bagi al-Ghazali adalah konsensus seluruh ulama dan masyarakat awam dalam waktu yang tidak terbatas. Bagi al-Ghazali yang penting bukan ijma'nya itu, tapi mengapa ijma' itu terjadi. Menurutnya, ijma' umat terhadap perlunya imamah dimaksudkan dalam rangka memelihara syari'at dan ketertiban agama, yang demikian tidak mungkin terwujud kecuali ada penguasa yang ditaati. ${ }^{47}$ Di samping alasan-alasan itu, al-Ghazali juga mengemukakan alasan lain dengan memperhatikan kenyataan sosial dan sifat alamiah manusia itu. Menurutnya manusia itu cenderung bermasyarakat agar mereka bisa kerjasama dan tolong-menolong dalam rangka memenuhi kebutuhan hidup mereka. Tapi karena dalam kerjasama dan tolong-menolong itu sering terjadi persaingan dan pertentangan, maka untuk mengatasinya diperlukan pemerintah atau penguasa, ${ }^{48}$ untuk melayani kepentingan rakyat.

Pemikiran al-Ghazali tersebut mengandung arti bahwa agama dan politik, dunia dan akhirat mempunyai kaitan erat yang tak dapat dipisahkan. Karena menurutnya tujuan manusia dalam bermasyarakat

118.

${ }^{45}$ Al-Ghazali, Al-Iqtishad fi al-I'tiqad, (Mesir: Maktabat al-Jund, 1972), hlm.

46Ijma' didefinisikan oleh al-Ghazali sebagai persetujuan seluruh umat Islam (ulama dan masyarakat awam), khususnya tentang masalah yang berkaitan dengan agama. Dengan alasan bila ulama telah bersepakat maka masyarakat awam akan mengikuti mereka. Dasar hukumnya hadis Nabi: "Umatku tidak akan bersepakat terhadap sesuatu yang salah atau sesat. Baca selengkapnya pada, Al-Ghazali, AlMusthashfa min Tlm al-Usbul, (Kairo: Maktabat al-Nahdhat al-Mishriyat, 1979), hlm. 110

${ }^{47}$ Muhammad Jalal Syaraf, Al-Fiker al-Islami..., hlm. 390.

${ }^{48} \mathrm{Al}-\mathrm{Ghazali}$, Ibya' 'Ulum al-Din, (Beirut: Dar al-Fikr, 1975), jilid III, hlm. 6.
Irfan Zulfikar, Konfigurasi Pemikiran Politik. Islam Imam al-Haramain

bukan hanya memenuhi kebutuhan dan mencari kebahagiaan materil semata, tapi lebih dari itu untuk mempersiapkan kehidupan yang lebih sejahtera dan abadi di akhirat. Hidup dan kehidupan di dunia bukan untuk dunia semata, tapi dunia adalah untuk agama dan agama untuk mengatur dunia. Keduanya dipenuhi secara seimbang dan adil. 49 Aktualisasi agama adalah pemahaman, penghayatan dan ibadah. In tidak akan tercapai kecuali dengan jasmani yang sehat dengan terpenuhinya kebutuhan-kebutuhan primer keamanan jiwa, dan hartanya terjamin. Bila kebutuhan-kebutuhan penting ini tak terpenuhi, ilmu dan amal juga tak akan tercapai yang keduanya merupakan jalan dan alat untuk memperoleh kebahagiaan. Jadi kesejahteraan materil menjadi syarat terlaksananya penghayatan dan pengamalan agama, dan agama berperan mengatur cara memperoleh kebutuhan materil. Ketertiban dunia, keamanan jiwa dan harta serta aktualisasi agama tidak akan terwujud kecuali dengan adanya penguasa yang ditaati untuk mengatur dunia menjadi ladang memperoleh kehidupan sejahtera di akhirat. Oleh karena itu al-Ghazali mengutip pendapat orang yang mengatakan : "Agama dan penguasa dua saudara kembar." 50

Dalam kaitan itu al-Ghazali merumuskan teori hubungan antara agama dan politik yang sangat dekat dan saling bergantung. Agama adalah dasar dan sultan (kekuasaan politik) adalah penjaganya. Sesuatu yang tanpa dasar akan runtuh dan suatu dasar tanpa penjaga akan hilang. Jadi sultan sangat dibutuhkan untuk menjamin ketertiban dunia. Ketertiban dunia merupakan keharusan untuk ketertiban pelaksanaan agama, dan ketertiban pelaksanaan agama merupakan keharusan untuk memperoleh kebahagiaan di akhirat. Inilah tujuan para Nabi. Jadi pengangkatan imam atau penguasa, wajib menurut hukum agama (syara'), dan tidak ada alasan untuk meninggalkannya. ${ }^{51}$ Dengan demikian ikatan antara agama dan dunia atau antara agama dan kekuasaan politik secara integral akan menciptakan wibawa kedaulatan negara di tangan kepala negara yang ditaati, dan memiliki

${ }^{49}$ Muhammad Jalal Syaraf, Al-Fiker al-Islami...,hlm. 389.

${ }^{50}$ Al-Ghazali, Al-Iqtishad...,hlm. 105-106.

${ }^{51}$ Ibid., hlm. 106. 
Al-Fikra: Jurnal Ilmiah Keislaman, Vol. 7, No. 2, Juli-Desember 2008

wibawa untuk melindungi kemaslahatan rakyat. ${ }^{52}$ Argumen-argumen al-Ghazali tersebut untuk membuktikan betapa perlunya mendirikan pemerintahan di satu sisi, dan untuk mendukung teori politiknya di sisi lain. Paradigma pemikirannya didasarkan pada kenyataan historis umat Islam, watak manusia sebagai makhluk sosial, dan karakter ajaran Islam yang memberi perhatian secara seimbang kepada urusan dunia dan akhirat serta keinginan untuk melaksanakan syari'at Islam. Hal ini, menurut Rosenthal, merupakan usahanya untuk mempertahankan institusi kekhalifahan sebagai simbol kesatuan masyarakat Muslim. ${ }^{53}$ Tetapi ada hal lain yang perlu diperhatikan mengapa al-Ghazali mensejajarkan politik dengan agama, yaitu persepsinya tentang posisi politik dalam ilmu pengetahuan. Menurutnya ilmu pengetahuan harus dibedakan antara ilmu syari'at dan ilmu yang bukan syari'at. Politik, etik dan matematika dan fisika termasuk dalam kategori kedua. ${ }^{54}$ Artinya kategori pertama seperti politik bersumber dari syari'at, dan kategori kedua bersumber dari akal dan pengalaman empiris. ${ }^{55}$ Jadi masalah siyasah termasuk kajian fiqh, ${ }^{56}$ yang berarti wewenang ulama fiqh. Faqih adalah orang yang mengetahui undang-undang politik, orang yang mengetahui cara menyelesaikan pertentangan di antara rakyat. Maka ia menjadi guru, pendamping dan pembimbing bagi kepala negara dalam memelihara agama dan mengurus dunia. ${ }^{57}$

Oleh karena itu, al-Ghazali mendefinisikan siyasat sebagai usaha memperbaiki kehidupan rakyat dengan membimbing mereka ke jalan yang lurus yang menyelamatkan mereka di dunia dan di akhirat. ${ }^{58}$ Politik baginya adalah alat untuk memperoleh kebahagiaan di dunia

${ }^{52}$ Muhammad Jalal Syaraf, Al-Fiker al-Islami...,hlm. 377.

${ }^{53}$ E.I.J. Rosenthal, Political Thought ini Medieval Islam, (London: Cambridge University Press, 1962), hlm. 38

${ }^{54}$ Harun Khan Shirwan, Studies in Muslim Political Thought and Administration, New Delhi: Heyderabad, 1945), hlm. 203. hlm. 27.

${ }^{55} \mathrm{Al}-\mathrm{Ghazali}$, Al-Munqir min al-Dhalalat, (Mesir: Maktabat al-Jund, 1961),

${ }^{56}$ Al-Ghazali, Al-Iqtishad..., hlm. 105.

${ }^{57}$ Muhammad Jalal Syaraf, Al-Fiker al-Islami..., hlm. 376.

${ }^{58} \mathrm{Ibid}$.
Irfan Zulfikar, Konfigurasi Pemikiran Politik Islam Imam al-Haramain

dan akhirat. Pengertian ini lebih luas dari pengertian politik sekarang yang hanya berkaitan dengan urusan sekuler (duniawi).

Abd al-Jabbar (salah seorang tokoh terkemuka Mu'tazilah) sependapat dengan Imam al-Haramain. Menurut Abd al-Jabbar dasar hukum pembentukan institusi Imamah adalah wajib berdasarkan pertimbangan akal untuk mewujudkan misi risalah syari'at Islam. ${ }^{59}$ Meskipun Abd al-Jabbar mendasarkan pembentukan lembaga pemerintahan (Imamah) pada pertimbangan akal pemikiran, tetapi bukanlah berarti kewajiban pembentukannya bersifat semu. Menurut Abd al-Jabbar, penetapan lembaga pemerintahan (Imamah) berdasar akal itu mendapat legitimasi syari'at. Dalam arti, syari'at juga mempunyai andil yang cukup besar dalam pembentukan lembaga pemerintahan (Imamah) itu. ${ }^{60}$

Dengan demikian, menurut penulis antara Imam al-Haramain (pemuka Sunni) dan Abd al-Jabbar (pemuka Mu'tazilah) pendapat mereka sama-sama mendasarkan pembentukan lembaga pemerintahan (Imamah) atas pertimbangan akal. Pendapat ini kelihatannya tidak jauh berbeda dengan ulama Sunni lainnya yang telah penulis kemukakan di atas, bahwa kewajiban pembentukan lembaga pemerintahan (Imamah) adalah berdasarkan ijma' (melalui proses akal).

\section{Sumber Kekuasaan}

Di dalam Kamus Umum Bahasa Indonesia secara etimologi kekuasaan diberi arti dengan "kuasa" (untuk mengurus, memerintah dan sebagainya); kemampuan; kesanggupan; kekuatan. ${ }^{61}$

Secara terminologi kekuasaan didefinisikan oleh Miriam Budiarjo adalah "kemampuan seseorang atau sekelompok manusia untuk mempengaruhi tingkah laku seseorang atau sekelompok orang sedemikian rupa, tingkah laku itu menjadi sesuai dengan keinginan dan

${ }^{59} \mathrm{Abd}$ al-Jabbar, Al-Mughni fi Abwab al-Taubid wa al-'Adl, (Kairo: Dar alMishriyyat li al-Ta'lif wa al-Tarjamat, 1965), hlm. 16-17.

${ }^{60} \mathrm{Abd}$ al-Jabbar, Syarb al-Ushul al-Khamsat, (Kairo: Maktabat Wahbat, 1965), hlm. 754.

${ }^{61}$ W.J.S. Poerwadarminta, Kamus Umum Babasa Indonesia, Jakarta: Balai Pustaka, 1983), hlm. 529. 
Al-Fikra: Jurnal Ilmiah Keislaman, Vol. 7, No. 2, Juli-Desember 2008

tujuan dari orang yang mempunyai kekuasaan tersebut". ${ }^{62}$ Selanjutnya Jean Bodein mendefinisikan kekuasaan sebagai suatu "kekuatan tertinggi yang abadi, tidak diwakilkan atau didelegasikan, tanpa batasan atau kondisi, tidak dapat dicabut dan dilukiskan. Karena kekuasaan adalah sumber hukum, hukum tentu tidak bisa membatasinya". ${ }^{63}$

Dari definisi di atas dapat dipahami bahwa kekuasaan adalah merupakan kemampuan atau kesanggupan seseorang untuk berbuat sesuatu dengan kewenangan yang dimilikinya.

Berkenaan dengan sumber kekuasaan, dari kajian para ahli teoritis politik membaginya kepada tiga teori : pertama, teori Ketuhanan, kedua, teori Kekuatan dan Ketiga, teori Kontrak Sosial. Menurut teori ketuhanan kekuasaan berasal dari Tuhan (Divine Right of King). Penguasa bertahta atas kehendak Tuhan sebagai pemberi kekuasaan kepadanya. ${ }^{64}$ Teori kekuatan adalah suatu teori yang mengatakan bahwa kekuasaan politik diperoleh melalui kekuatan dalam persaingan antar kelompok. Negara dibentuk oleh pihak yang menang, dan kekuatanlah yang membentuk kekuasaan dan pembuat hukum. ${ }^{65}$ Teori ini dikemukakan juga Ibnu Khaldun. Menurut Ibn Khaldun masyarakat manusia memerlukan al-wazi’ (pemimpin) untuk melaksanakan kekuasaan dan memperbaiki kehidupan masyarakat dan mencegah perbuatan aniaya di antara sesama. Al-Wazi' diikuti karena memiliki kekuatan dan pengaruh atas masyarakatnya. Hubungan sosial masyarakatnya berdasarkan hubungan keturunan yang disebutnya 'ashabiyat (solidaritas kelompok) sebagai perekat kekuatan kelompok itu. Dengan demikian suatu daulah (pemerintahan) dapat terbentuk apabila suatu kelompok masyarakat mampu mengalahkan kelompok masyarakat lainnya. Dan dengan kemenangan itu ia memperoleh kekuasaan politik. ${ }^{66}$ Sedangkan teori kontrak sosial adalah suatu teori

${ }^{62}$ Miriam Budiarjo, Dasar-Dasar Ilmu Politik, Jakarta: Gramedia Pustaka Utama, 1999), hlm. 35.

${ }^{63}$ Dikutip dari George Sabine, A History of Political Theory, (Hindsale: Dryden Press, 1973), hlm. 377.

${ }^{64}$ Krenenburg dan TK. Sabaruddin, Ilmu Negara Umum, (Jakarta: Pradya Paramita, 1986), hlm. 9.

${ }^{65} \mathrm{~F}$. Isywara, Pengantar Ilmu Politik, (Bandung: Angkasa, 1982), hlm. 153.

${ }^{66}$ Ibn Khaldun, Muqaddimat, (Beirut: Dar al-Fikr, tt.), hlm. 139.
Irfan Zulfikar, Konfigurasi Pemikiran Politik. Islam Imam al-Haramain

yang menerangkan kekuasaan diperoleh melalui sebuah perjanjian masyarakat. Artinya kekuasaan politik bersumber dari rakyat, dan legitimasinya melalui perjanjian masyarakat. Dengan kata lain terjadinya penyerahan kekuasaan oleh anggota masyarakat kepada seseorang atau lembaga. ${ }^{67}$

Dari kajian yang penulis teliti terhadap pemikiran politik Imam al-Haramain, secara eksplisit tidak diperoleh keterangan teori beliau mengenai sumber kekuasaan bagi kepala negara. Apakah menurut teori ketuhanan, teori kekuatan, dan atau teori kontrak sosial. Namun, untuk mengetahui hal ini penulis memahaminya berdasarkan tafsiran terhadap pemikiran dan gagasan beliau mengenai proses terbentuknya lembaga pemerintahan (negara), cara pemilihan kepala negara dan pemberhentian kepala negara (akan datang penulis uraikan). Melihat kepada pemikiran dan gagasan beliau mengenai proses terbentuknya lembaga pemerintahan (negara), cara pemilihan kepala negara dan pemberhentian kepala negara tersebut, penulis menilai bahwa Imam al-Haramain lebih mungkin ditarik kepada paham teori kontrak sosial. Artinya, sumber kekuasaan bagi Imam al-Haramain berasal dari masyarakat.

Terhadap proses terbentuknya negara menurut Imam alHaramain adalah atas dasar kehendak manusia sebagai makhluk sosial atau makhluk politik untuk berkumpul di suatu tempat dalam rangka kerjasama dan tolong-menolong guna memenuhi kebutuhan hidup mereka. Tapi tabi'at manusia yang demikian itu dikaitkan Imam alHaramain dengan keyakinan agama. Sebagai ciptaan dan kehendak Tuhan atas manusia. Dalam kerjasama itu menurut Imam alHaramain, mereka memerlukan seorang pemimpin yang akan mengatur urusan mereka. ${ }^{68}$ Untuk tampilnya seorang pemimpin menurut Imam al-Haramain harus diangkat melalui proses pemilihan yang dilakukan oleh abl al-aqd wa al-halli, yang disertai dengan baiat atau persetujuan masyarakat. ${ }^{69}$ Menurut Sudirman M. Johan istilah abl hlm. 79 .

${ }^{67}$ Deliar Noer, Pemikiran Politik di Negara Barat, (Jakarta: Rajawali, 1982),

${ }^{68}$ Imam al-Haramain, Al-Irsyad..., hlm. 423.

${ }^{69}$ Imam al-Haramain, Al-Ghiyatsi Ghiyats al-Umam fi Tiyats al-Zhulam, Tahqiq Abdul al-Ashim al-Dayb, I, (Qathar: al-Syuun al-Dinayat, 1400), hlm. 68. 
Al-Fikra: Jurnal Ilmiah Keislaman, Vol. 7, No. 2, Juli-Desember 2008 al-'aqd wa al-halli ini merupakan istilah yang pertama sekali dikenal di kalangan pemikir politik Islam, yang dikemukakan oleh Imam alHaramain. Istilah yang hampir sama dengan abl al-'aqd wa al-halli ini adalah istilah yang dikemukakan oleh Imam al-Mawardi yaitu abl alikhtiyar. ${ }^{70}$ Untuk kalangan Mu'tazilah istilah abl al-'aqd wa al-halli dikenal dengan istilah abl al-satr wa al-din sebagaimana yang dikemukakan oleh Abd al-Jabbar bertugas untuk menentukan atau memilih orang yang akan memangku jabatan imam. ${ }^{71}$ Berdasarkan proses ini, menurut Imam al-Haramain terlihat bahwa telah terjadi "perjanjian sosial" di antara kedua belah pihak atas dasar sukarela. ${ }^{72}$

Dengan demikian, menurut hemat penulis, Imam al-Haramain dalam menentukan sumber kekuasaan adalah berdasarkan atas teori kontrak sosial. Yakni umat Islam itu sendiri yang menyerahkan kekuasaan kepada umat Islam lainnya dengan jalan memilih wakilwakil. Dalam pengertian, hubungan antara abl al-hall wa al-'aqd (legislatif) dengan kepala negara (eksekutif) merupakan hubungan antara dua pihak peserta kontrak sosial yang melahirkan kewajiban dan hak bagi kedua belah pihak atas dasar timbal balik. Oleh sebab itu, kepala negara selain berhak ditaati oleh rakyatnya dan menuntut adanya partisipasi dan loyalitas penuh mereka; sebaliknya kepala negara mempunyai kewajiban yang harus dipenuhi terhadap rakyatnya seperti memberi perlindungan, mengelola kepentingan mereka dengan baik dan penuh tanggung jawab. Dan wakil-wakil (abl al-hall wa al-'aqd) ini berhak membuat hukum baru selama tidak bertentangan dengan prinsip-prinsip umum dalam al-Qur'an dan Sunnah. Selanjutnya kekuasaan yang diberikan kepada kepala negara (khalifah) terpilih dapat dipertahankan kekuasaannya, selama kepala negara (khalifah) mendapat kepercayaan dari rakyat dan ia benar-benar mempunyai kemampuan untuk menjalankan kepentingan umat, sesuai dengan kontrak (perjanjian) yang telah dilakukan antara kepala negara (khalifah) dan rakyat (umat).

${ }^{70}$ Al-Mawardi, Abkam..., hlm. 6.

${ }^{71} \mathrm{Abd}$ al-Jabbar, Al-Mughni..., hlm. 100

${ }^{72}$ Imam al-Haramain, Al-Irsyad..., hlm. 423.
Irfan Zulfikar, Konfigurasi Pemikiran Politik. Islam Imam al-Haramain

Berbeda dengan Imam al-Haramain, Ibn Abi Rabi’ lebih dekat ditarik kepada teori ketuhanan. Hal ini didasarkan pada pendapatnya bahwa Allah mengangkat penguasa-penguasa bagi masyarakat. Penguasa-penguasa itu mendapat pancaran Ilahi dan menetapkan mereka dengan karamah-Nya. ${ }^{73}$ Namun dalam hal ini, Ibnu Abi Rabi' tidak menjelaskan apakah seorang penguasa yang mendapat pancaran Ilahi ditetapkan melalui pemilihan atau penunjukan. Dengan demikian, pernyataan Ibn Abi Rabi' dapat dipahami bahwa, sumber kekuasaan kepala negara bukan berasal dari rakyat, melainkan datang dari Allah yang melimpahkan-Nya kepada sejumlah kecil orang pilihan. Pendapat Ibn Abi Rabi' ini sejalan dengan konsep teori ketubanan yaitu kekuasaan berasal dari Tuhan (Divine Rights of King).

Imam al-Ghazali dalam hal ini sependapat dengan Ibn Abi Rabi'. Imam al-Ghazali dengan mendasarkan kepada ayat 59 surat alNisa' yang berbunyi :

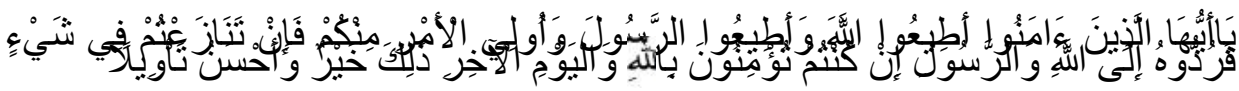
Artinya : 'Hai orang-orang yang beriman ta'atilah Allah dan ta'atilab Rasul (Nya), dan ulil amri di antara kamu”. (Q.S. al-Nisa : 59). ${ }^{74}$

Ayat di atas memerintahkan orang-orang mukmin untuk taat kepada Allah, kepada RasulNya dan kepada para pemimpin. Selanjutnya berdasarkan surat Ali Imran ayat 26 yang berbunyi :

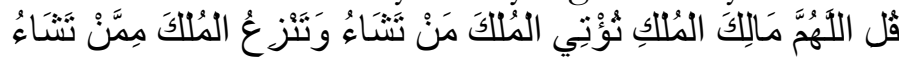

Artinya : "Katakanlah : "Wahai Tuban yang mempunyai kerajaan, Engkau berikan kerajaan kepada orang yang Engkau kehendaki dan Engkau cabut kerajaan dari orang yang Engkau kehendaki". ${ }^{75}$

Ayat tersebut menegaskan bahwa Allah memberikan kerajaan (kekuasaan) kepada yang Ia kehendaki. Berdasarkan ayat di atas, maka rakyat wajib mengikuti dan mentaatinya (kepala negara), tidak boleh menentangnya. Untuk itu, menurutnya dalam kenyataan Tuhan telah memilih di antara cucu-cucu Adam menjadi Nabi-Nabi dan para

73Ibn Abi Rabi', Suluk al-Malik, fi Tadbir al-Mamalik, (Kairo : Dar al-Sya'ab, 1970), hlm. 102

${ }^{74}$ DEPAG RI., Al-Qur'an dan..., hlm. 238.

${ }^{75}$ Ibid., hlm. 79. 
Al-Fikra: Jurnal Ilmiah Keislaman, Vol. 7, No. 2, Juli-Desember 2008

pemimpin. Hal ini beliau nyatakan bahwa Allah telah memilih bani Adam dua kelompok pilihan : pertama, para Nabi yang bertugas menjelaskan kepada hamba-hamba Allah tentang jalany benar yang akan membawa kebahagiaan dunia dan akhirat, dan kedua, para raja (kepala negara), dengan tugas menjaga agar hamba-hamba Allah tidak saling bermusuhan dan saling melanggar hak, dan memandu mereka ke arah kedudukan yang terhormat serta dengan kebijaksanaannya ia mewujudkan kemaslahatan rakyat. $^{76}$ Al-Ghazali sendiri mengakui bahwa kepala negara atau sulthan adalah bayangan Allah di atas bumiNya, maka wajib dicintai, harus ikut dan tunduk serta tidak dibenarkan menentang. Alur pemikiran al-Ghazali tersebut, menurut Muhammad Jalal Syaraf dan Ali Abd al-Mu'thi Muhammad, mengandung arti bahwa kekuasaan kepala negara itu muqaddas (suci). Karenanya rakyat wajib mentaati segala perintahnya. Sistem pemerintahan dalam pemikiran al-Ghazali adalah teokrasi. ${ }^{77}$

Oleh karena itu, dapat dipahami bahwa Imam al-Ghazali dalam hal ini menganut teori ketuhanan. Hal ini terlihat dari komentar beliau di bahwa kepala negara sebagai bayangan Allah di bumi, di samping itu juga kepala negara sendiri adalah suci (muqaddas) serta kekuasaannya tidak datang dari rakyat sebagaimana yang telah dikemukakan oleh gurunya Imam al-Haramain di atas. Meskipun seseorang menjadi sultan atau kepala negara atas kehendak Allah, namun menurut alGhazali, ia juga harus mendapat tafwidh (penyerahan kekuasaan) dan tauliyat (pengangkat dari orang lain). Dalam hal ini beliau berbeda dengan Ibn Abi Rabi' di atas. Menurut al-Ghazali ada tiga cara untuk memperoleh tafwidh dan tauliyat itu, yaitu dengan cara penetapan dari Nabi, penetapan dari sultan yang sedang berkuasa dengan menunjuk putra mahkota (wilayat al-'abd) dari putra-putranya atau orang Quraisy lainnya, dan pengangkatan dari pemegang kekuasaan, yang diperkuat dengan bai'at oleh ulama yakni abl al-halli wa al-'aqd..$^{78}$ Bai'at yang yang dimaksud ada bai'at yang sifatnya terbatas.

\footnotetext{
$40-41$.

${ }^{7}$ Muhammad Jalal Syaraf, Al-Fikr al-Siyasi...,hlm. 376

${ }^{78}$ Al-Ghazali, Al-Iqtishad..., hlm. 106.
}

${ }^{76}$ Al-Ghazali, Al-Tibr al-Masbuk, fi Nasihat al-Mulk, (Kairo: tp., 1317 H.), hlm.
Irfan Zulfikar, Konfigurasi Pemikiran Politik Islam Imam al-Haramain

Dengan demikian, antara Imam al-Haramain dan Ibn Abi Rabi' serta Imam al-Ghazali, ada kesesuaian terhadap pendapat mereka di atas. Hanya saja penulis dapat memahami, bahwa terjadinya perbedaan di antara mereka dalam menentukan sumber kekuasaan bagi kepala negara, terletak pada pemahaman mereka tentang hakikat eksistensi kepala negara itu sendiri berasal.

\section{Syarat-Syarat Kepala Negara}

Para pemikir politik klasik sunni mencita-citakan terwujudnya pelaksanaan syari'at Islam, keadilan dan kesejehteraan rakyat melalui kekuasaan politik dan pemerintahan. Hal ini tercermin dalam syaratsyarat kepala negara yang mereka kemukakan.

Imam al-Haramain sebagai salah seorang tokoh pemikir politik sunni, berpendapat bahwa seorang kepala negara harus memenuhi syarat-syarat sebagai berikut : Pertama, harus seorang mujtahid, sehingga ia tidak butuh minta fatwa kepada orang lain dalam beberapa hal. Kedua, mampu mengurus kemaslahatan segala sesuatu dan memeliharanya dengan baik. Ketiga, punya kelebihan dalam mengatur militer dan mempertahankan pertahanan. Keempat, memiliki wawasan yang luas untuk memikirkan kepentingan kaum muslimin. Kelima, memiliki sifat lemah lembut. Keenam, menegakkan hukum bagi pelanggar hukum. Dan ketujuh, Muslim laki-laki yang merdeka. ${ }^{79}$ Formulasi syarat-syarat kepala negara yang diajukan oleh Imam alHaramain tersebut, jika diambil natijabnya menurut hemat penulis, pada dasarnya Imam al-Haramain menghendaki agar seorang kepala negara harus mempunyai kemampuan (kifayat) dalam menggunakan kekuasaannya untuk mengatur semua yang tersebut di atas.

Berbeda dengan Imam al-al-Haramain, Imam Mawardi menempatkan suku Qurasiy sebagai syarat bagi kepala negara (pemimpin). Hal ini terlihat dari syarat-syarat yang diajukannya sebagai berikut : Pertama, Keseimbangan (al-'adalab) yang memenuhi semua kriteria. Kedua, Mempunyai ilmu pengetahuan yang membuatnya dapat melakukan ijtihad untuk menghadapi kejadian-kejadian yang timbul
${ }^{79}$ Imam al-Haramain, Al-Irsyad..., hlm. 426-427. 
Al-Fikra: Jurnal Ilmiah Keislaman, Vol. 7, No. 2, Juli-Desember 2008

dan untuk membuat kebijakan hukum. Ketiga, pancaindranya lengkap dan sehat dari pendengaran, penglihatan, lidah dan sebagainya, sehingga ia dapat menangkap dengan benar dan tepat apa yang ditangkap oleh indranya itu. Keempat, tidak ada kekurangan pada anggota tubuhnya yang menghalanginya untuk bergerak dan cepat bangun. Kelima, visi pemikirannya baik, sehingga ia dapat menciptakan kebijakan bagi kepentingan rakyat dan mewujudkan kemaslahatan mereka. Keenam, mempunyai keberanian dan sifat menjaga rakyat, yang membuatnya mempertahankan rakyatnya dan memerangi musuh. Ketujuh, mempunyai nasab dari suku Quraisy. Untuk kualifikasi terakhir ini Imam al-Mawardi menekankannya berdasarkan pada nash dan ijma' yang terjadi pada pertemuan Tsaqifah Bani Sa'idah yang berakhir dengan terpilihnya Abu Bakar secara ijma'. ${ }^{80}$ Mengomentari syarat terakhir tersebut, Lambton dan Rosenthal berpendapat, alMawardi mengedepankan persyaratan itu bertujuan untuk mempertahankan dan mengamankan kekuasaan politik dinasti Abbasiyah. Waktu itu mendapat tantangan dari Syi'ah Bani Buwaihi dan Bani Fathimiyah. Yang tersebut terakhir tidak diakui oleh partisan Abbasiyah sebagai keturunan Quraisy. ${ }^{81}$

Sependapat dengan Imam al-Mawardi, Imam al-Ghazali juga memasukkan suku Quraisy sebagai syarat bagi kepala negara. Syaratsyarat kepala negara menurut Imam al-Ghazali adalah sebagai berikut : Pertama, harus laki-laki yang dewasa. Kedua, berakal sehat. Ketiga, sehat pendengaran. Keempat, sehat penglihatan. Kelima, merdeka. Keenam, berasal dari suku Quraisy berdasarkan hadis Nabi : "Para pemimpin harus dari Quraisy". Ketujuh, punya kekuasaan nyata (al-najdat). Kedelapan, memiliki kemampuan (kifayat). Kesembilan, wara'. Dan kesepuluh, berilmu. ${ }^{82}$

Lain halnya Imam al-Mawardi dan Imam al-Ghazali, Imam alHaramain tidak menempatkan suku Quraisy sebagai salah satu syarat kepala negara, karena syarat ini menurutnya suatu masalah yang diperselisihkan, maka tidak boleh membuat suatu statemen yang pasti.

${ }^{80} \mathrm{Al}-\mathrm{Mawardi}$, Abkam ..., hlm. 6.

${ }^{81}$ Lambton, State and..., hlm. 89, Rosenthal, Political Though..., hlm. 27.

${ }^{82}$ Al-Ghazali, Fadhaih al-Batbiniyah, (Kairo : tp., 1964), hlm. 180.
Irfan Zulfikar, Konfigurasi Pemikiran Politik Islam Imam al-Haramain

Apalagi masalah ini adalah lapangan ijtihad, tidak boleh mutlakmutlakan. ${ }^{83}$ Pendapat Imam al-Haramain ini diperkuat oleh Ibn Taimiyah. Ibn Taimiyah menambahkan, lebih dari itu persyaratan ini bertentangan dengan prinsip ajaran al-Qur'an tentang konsep persamaan. Sebagaimana firman Allah dalam surat al-Hujurat ayat 45 yang berbunyi :

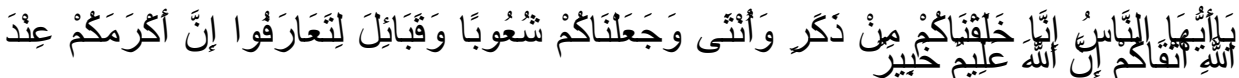

Artinya : "Hai manusia sesunggubnya Kami menciptakan kamu dari seorang laki-laki dan seorang perempuan dan menjadikan kamu berbangsabangsa dan bersuku-suku supaya kamu saling kenal mengenal. Sesunggunya orang yang paling mulia di antaramu di sisi Allah ialah orang yang paling bertaqwa. Sesunggubnya Allah Maha Mengetabui lagi Maha Penyayang". (Q.S. al-Hujurat : 13)..$^{84}$

Jadi persyaratan itu (mesti suku Quraisy), menurut Ibn Taimiyah sekalipun didasarkan pada hadis, hal ini bertentangan dengan nash yang lebih rajih di atas.

Pendapat Imam al-Haramain sendiri tentang kepala negara boleh non-Quraisy menurut hemat penulis, sangat logis sekali, dan beliau sangat kondisionalis (kontekstual) sekali dalam memahami nash (hadis Nabi) tentang kepala negara mesti dari suku Quraisy. Sebab, dengan luasnya daerah ditambah lagi dengan perubahan sosio-kultur (peradaban) manusia yang semakin maju, bukan tidak mustahil nonQuraisy mampu tampil sebagai seorang kepala negara dalam sebuah pemerintahan Islam (Khilafah Islamiyah), artinya kepemimpinan umat Islam bukan hak monopoli Quraisy.

Menurut hemat penulis, jika diperhatikan persyaratan yang diajukan oleh Imam al-Haramain, Imam al-Mawardi dan Imam alGhazali di atas, pada substansinya adalah kepala negara haruslah seorang yang berkualitas dan mampu serta sanggup melaksanakan fungsi dan tugasnya sebagai kepala negara (pemimpin) dalam menciptakan suasana yang aman, damai dan tentram serta makmur untuk kemaslahatan umat (rakyat).

${ }^{84}$ DEPAG RI., Al-Qur'an dan..., hlm. 847. 
Al-Fikra: Jurnal Ilmiah Keislaman, Vol. 7, No. 2, Juli-Desember 2008

\section{Mekanisme Pengangkatan Kepala negara}

Dalam menentukan mekanisme pengangkatan kepala negara, baik al-Qur'an maupun hadis secara eksplisit tidak ada yang menjelaskannya. Sehingga para pemikir politik Islam berusaha untuk merumuskan dengan cara mengadopsi pengalaman yang telah dilakukan oleh Khulafa' al-Rasyidin. Sebagaimana telah dikemukakan di atas (pada pembahasan pembentukan lembaga pemerintahan), menurut Imam al-Haramain jika nash tentang penetapan imam terhadap Ali telah gugur, maka cara yang dilakukan adalah sistem pemilihan (al-ikhtiar). ${ }^{85}$

Pendapat Imam al-Haramain ini sama dengan pendapat $\mathrm{Al}$ Baqillani. Menurut al-Baqillani, ditolaknya penunjukkan Ali sebagai Imam, karena didasarkan atas khabar ahad, bukan atas khabar mutawatir. Lebih lanjut al-Baqillani menyebutkan, tak ada orang yang mengetahui tentang penunjukkan Ali oleh Nabi untuk memangku jabatan Imam. Terpilihnya Abu Bakar menjadi khalifah pertama dalam pertemuan Tsaqifah Bani Sa'idah, menurut pendapatnya, adalah konsensus umat Islam sekaligus menolak kepercayaan Syi'ah sebagai suatu yang palsu sejak awal. ${ }^{86}$ Jika cara penetapan tidak sah, kata alBaqillani, maka sistem pengangkatan Imam harus dengan jalan pemilihan (al-Ikhtiyar) oleh abl al-halli wa al-'aqd (wakil rakyat). ${ }^{87}$

Dalam mekanisme pengangkatan kepala negara, Imam alHaramain juga tidak mensyaratkan adanya ijma', tapi hal itu mesti dilakukan walaupun belum ada ijma' umat dan abl al-halli wa al-'aqd

${ }^{85}$ Imam al-Haramain, Al-Irsyad..., hlm. 424. Tentang pengangkatan kepala negara dilakukan dengan cara pemilihan (ikhtivar) para tokoh pemikir politik sunni semuanya sepakat, kecuali dari kelompok Syi'ah. Golongan Syi'ah mengklaim bahwa seorang Imam itu adalah ma'shum, sehingga mereka tidak mengenal adanya pemecatan Imam dari jabatannya. Dan Syi'ah pun tidak mengenal adanya suksesi (proses pemilihan) selama Imam masih hidup. Namnu demikian, dalam doktrin imamat Syia'h berlangsungnya suksesi, apabila Imam wafat. Sudirman M. Johan, op.cit. hlm. 150.

86Dikutip dalam Muhammad Yusuf Musa, Nizham al-Hukm fi al-Islam, (Kairo : Dar al-Kitab al-'Arabi, 1963), hlm. 74.

${ }^{87}$ Lambton, State and..., hlm. 73.
Irfan Zulfikar, Konfigurasi Pemikiran Politik. Islam Imam al-Haramain

(wakil rakyat) atas pengangkatannya itu". ${ }^{88}$ Jika diperhatikan pendapat Imam al-Haramain ini, penulis menilai, tampaknya Imam al-Haramain membedakan antara pembentukan pemerintahan yang didasarkan atas ijma' dan pengangkatan kepala negaranya yang mengabaikan ijma'. Pendapat Imam al-Haramain tersebut didasarkan pada pengangkatan Abu Bakar oleh sekelompok elit sahabat. Waktu itu menurut Imam alHaramain, peristiwa tersebut belum tersebar kepada sahabat lain, tapi mereka tidak menentangnya. ${ }^{89}$ Artinya bai'at umum oleh rakyat kepada Abu Bakar baru terlaksana setelah elit sahabat menyetujui pengangkatannya itu. Apabila ijma' tidak menjadi syarat dalam pengangkatan kepala negara, maka jumlah pemilih, bagi Imam alHaramain, tidak menjadi ukuran sahnya suatu pemilihan. Ia dapat menerima pengangkatan imam oleh seorang dari anggota abl al-halli wa al-'agd. Karena masalah ini menurutnya adalah lapangan ijtihad, berada di luar bidang atau masalah qath'i (pasti). ${ }^{90}$

Menurut hemat penulis, Imam al-Haramain tampaknya tidak konsekuen dengan konsep ijma' yang ia kemukakan sebagai yang telah disebut pada pembahasan terdahulu. Jika konsep ijma'nya diterapkan dalam pemilihan kepala negara, maka alur pemikirannya tampak lurus. Sebab kesepakatan semua anggota pemilih menurut penulis, akan memungkinkan lagi untuk mampu menyerap semua aspirasi yang berkembang di tengah masyarakat. Oleh karena itu pula, Imam alHaramain tidak mensyaratkan adanya saksi dalam hal pengangkatan imam, sebagaimana ditetapkan oleh sebagian ulama sunni lain. Lagilagi Imam al-Haramain beralasan melihatnya sebagai lapangan ijtihad. Jadi pengangkatan imam sifatnya sangat terbatas, tergantung kepada keberadaan lembaga pemilih.

Pendapat Imam al-Haramain tersebut kelihatannya tidak jauh berbeda dengan al-Baqillani. Menurut al-Baqillani, pemilihan kepala negara sah sekalipun dilakukan oleh seorang wakil rakyat (abl al-halli wa al'-aqd). Al-Baqillani menetapkan seseorang yang pantas untuk memangku jabatan Imam. Setelah kepala negara terpilih, kaum

88Imam al-Haramain, Al-Irsyad..., hlm. 246.

${ }^{89}$ Imam al-Haramain, Al-Irsyad., Ibid.

${ }^{90}$ Ibid. 
Al-Fikra: Jurnal Ilmiah Keislaman, Vol. 7, No. 2, Juli-Desember 2008

Muslimin harus hadir memberikan bai'at kepadanya dan memberitahukan kepada rakyat banyak. ${ }^{91}$ Pandangan al-Baqillan tersebut, menurut Lambton untuk menentang klaim tentang adanya pendapat Ali secara rahasia untuk menjadi Imam. ${ }^{92}$ Sedangkan pemberitahuan khalifah terpilih merupakan sikap hati-hati terhadap adanya bahaya dari kekuatan militer secara rahasia mengangkat kepala negara baru. ${ }^{93}$

Mengenai jumlah kepala negara yang berkuasa, Imam alHaramain dapat menerima dua orang kepala negara yang berkuasa pada waktu yang sama di dalam wilayah yang luas, berjauhan dan terpisah. Sedangkan dalam wilayah yang sempit, hanya boleh satu imam atas dasar ijma'. ${ }^{94}$ Pendapat Imam al-Haramain ini, sama dengan pendapat al-Baghdadi. Menurut Al-Baghdadi, boleh dua orang Imam berkuasa secara simultan karena wilayah mereka terbagi; dipisahkan oleh laut seperti daulah Umayyah di Spanyol dan daulah Abbasiyah di Baghdad. Namun demikian, Al-Baghdadi mengakui tidak adanya kesepakatan di antara orang-orang sunni mengenai jumlah imam yang boleh berkuasa pada waktu yang bersamaan. Lebih lanjut al-Baghdadi mengatakan, golongan mayoritas kami mempertahankan bahwa tidak dibolehkan adanya dua orang imam yang harus ditaati secara wajib."95

Menurut hemat penulis, sangat beralasan sekali pendapat Imam al-Haramain dan al-Baghdadi di atas. Sebab, dalam wilayah yang luas sangat sulit sekali bagi seorang kepala negara untuk memerintah. Dan sebagai solusi alternatif jalan yang terbaik itu adalah dengan cara membagi dua kekuasaan (dua kepala negara). Dari pendapat mereka di atas, penulis juga memahami bahwa mereka tidak ingin terjadi adanya perpecahan di antara umat Islam, yang ketika itu telah berdiri pemerintahan baru yaitu daulah Fathimiyah yang Syi'ah di Mesir dan daulah Umayyah, rival Abbasiyah, di Spanyol.

Lain halnya dengan Imam al-Haramain dan al-Baghdadi, alBaqillani dan al-Mawardi tidak membenarkan "legalitas adanya dua

${ }^{91}$ Lambton, State and..., hlm. 73.

${ }^{92}$ Ibid

${ }^{93}$ Ibid.

${ }^{94}$ Ibid., hlm. 425.

${ }^{95}$ Ibid., hlm. 78-79.
Irfan Zulfikar, Konfigurasi Pemikiran Politik. Islam Imam al-Haramain

orang atau lebih kepala negara atau Imam pada satu waktu yang bersamaan". ${ }^{96}$ Pendapat mereka ini menurut penulis, secara implisit untuk menolak keabsahan klaim Fathimiyah yang Syi'ah dan daulah Umayyah, rival Abbasiyah, di Spanyol, yang dinilai sebagai kekuatan politik yang berbahaya terhadap kekuasaan Bani Abbasiyah di Baghdad. Hal ini dapat penulis pahami dari pernyataan mereka yang mengatakan bahwa "sekalipun umat Islam telah terpecah ke dalam berbagai aliran dan masing-masing mengklaim berhak punya pemerintahan sendiri, tetapi tidak bisa dibenarkan. Sedangkan kepala negara yang sah adalah yang terdahulu yang diangkat. Bila ada yang menentangnya, maka ia harus diperangi". ${ }^{97}$

Pandangan mereka ini menurut penulis, dari satu segi dinilai positif, mereka ingin memelihara keutuhan persatuan umat Islam. Tapi dari segi yang lain pendapat mereka itu kelihatan kaku dan malah mempertajam pertentangan dan permusuhan. Lagi pula doktrin itu tidak mungkin dilaksanakan, sebab umat ketika itu mendiami daerah yang luas serta pemerintahan sendiri.

\section{Mekanisme Pemberhentian Kepala Negara}

Tentang mekanisme pemberhentian kepala negara, sebagaimana mekanisme pengangkatan kepala negara al-Qur'an dan hadis juga tidak secara eksplisit menjelaskannya. Pada dasarnya para pemikir politik sunni tidak mengenal adanya pembatasan jabatan kepala negara. Sama seperti Sunni, Mu'tazilah dan Syi'ah juga tidak mengenal adanya pembatasan jabatan kepala negara tersebut. Selama kepala negara masih hidup tidak ada suksesi. Suksesi akan berlangsung setelah ia wafat. ${ }^{98}$ Namun demikian, ulama Sunni hanya membahas kemungkinan-kemungkinan yang menyebabkan terjadinya hal itu.

Imam al-Haramain, meskipun pada prinsip tidak membatasi jabatan kepala negara, suksesi juga bisa dipercepat. Menurut Imam alHaramain, kepala negara yang diangkat melalui pemilihan tidak boleh

${ }^{9} \mathrm{Al}$-Baqillani, Nushush al-Fiker al-Siyasi al-Islami, Tahqiq Yusuf Ibish, (Beirut: ttp. 1966), hlm. 193; dan Al-Mawardi, Abkam..., hlm. 7.

${ }^{97}$ Al-Baqillani, Ibid.; Al-Mawardi, Ibid.

${ }^{98}$ Sudirman M. Johan, Politik Keagamaan..., hlm. 150. 
Al-Fikra: Jurnal Ilmiah Keislaman, Vol. 7, No. 2, Juli-Desember 2008

memberhentikannya, kecuali ada suatu peristiwa atau perubahan sesuatu dalam dirinya yang membolehkan untuk itu (suksesi). Hal ini ditegaskan Imam al-Haramain, telah menjadi kesepakatan ulama. Lebih lanjut Imam al-Haramain menegaskan, apabila kepala negara itu fasiq dan fajir (melakukan perbuatan dosa dan tidak berlaku adil), maka memberhentikannya adalah mungkin. ${ }^{99}$ Dikatakan demikian mungkin menurut Imam al-Haramain, karena tidak ada dasar hukum (ketetapan) untuk memberhentikannya. Pengunduran diri seorang kepala negara bila ia tidak lagi merasa mampu memikul tanggung jawab kedudukannya, juga adalah mungkin. Hal ini ia dasarkan kepada kasus Hasan bin Ali bin Abi Thalib mengundurkan diri dari jabatannya karena lemah dan menyerahkannya kepada Mu'awiyah bin Abi Sufyan. ${ }^{100}$

Seperti halnya Imam al-Haramain, al-Baqillani juga berpendapat adanya kemungkinan terjadinya suksesi. Menurut al-Baqillani, walaupun umat memiliki hak untuk menetapkan seseorang yang memiliki kualifikasi untuk menduduki jabatan khalifah, namun menurut al-Baqillani tidak punya hak membatalkan kontrak atau perjanjian dua belah pihak yang telah dibuat. Hal ini hanya bisa dilakukan bila ada kasus atau keadaan yang mengharuskan untuk itu. ${ }^{101}$ Kasus dan keadaan yang menyebabkan pemberhentian kepala negara, menurut beliau disebabkan : pertama, tidak jujur, berbuat bid'ah, tidak adil dan berbuat dosa, kedua, lemah fisik dan mental, seperti gila dan kehilangan kemampuan, tuli dan bisu atau lanjut usia sehingga tidak lagi mampu melaksanakan tanggung jawab dan tugasnya, ketiga. kehilangan kebebasan karena ditawan oleh musuh. ${ }^{102}$

Imam al-Mawardi, berpendapat sama dengan Imam al-Haramain dan al-Baqillani di atas. Menurut al-Mawardi, apabila kepala negara melaksanakan dan menjamin hak-hak rakyat, berarti pula ia telah melaksanakan dan memelihara hak-hak Allah. ${ }^{103}$ Karena kepala negara itu menghimpun hak-hak umum secara integral antara hak Allah dan

${ }^{99}$ Imam al-Haramain, Al-Irsyad,..., hlm. 425

${ }^{100} \mathrm{Ibid}$., hlm. 425-426.

${ }^{101}$ Lambton, State and..., hlm. 74.

${ }^{102}$ Ibid.

${ }^{103}$ Al-Mawardi, Ahkam..., hlm. 17.
Irfan Zulfikar, Konfigurasi Pemikiran Politik Islam Imam al-Haramain

hak rakyat. ${ }^{104}$ Jadi pelaksanaan syari'at dan terwujudnya kemaslahatan rakyat menurut Imam al-Mawardi, menjadi tujuan utama penyelenggaraan pemerintahan. Artinya kekuasaan politik adalah alat untuk melaksanakan seperangkat hukum yang disyari'atkan oleh Allah dan alat untuk mewujudkan kemaslahatan rakyat. Konsistensi kepala negara mewujudkan hak umat dan hak Allah, menurut al-Mawardi, menyebabkan rakyat wajib mentaati dan membelanya selama tidak berubah keadaannya. Jika kepala negara sudah berubah, maka dapat dilakukan pemutusan kontrak perjanjian. Yang dimaksud dengan berubah keadaannya adalah kepala negara yang cacat keadilannya, dan sesuatu menimpa fisiknya sehingga tidak mampu menjalankan pemerintahan. Kepala negara yang cacat keadilannya karena ia berbuat salah dan fasiq, keluar dari jalan yang benar, perbuatan dan keyakinannya bercampur dengan hal-hal tercela dan munkar lantaran menurutkan hawa nafsu. Sedangkan sesuatu yang menimpa fisiknya dan membuatnya tidak mampu lagi menjalankan roda pemerintahan menurut al-Mawardi adalah sebagai berikut : pertama, kehilangan panca indera, kedua, kehilangan organ-organ tubuh lainnya, dan ketiga, kehilangan kebebasan untuk bertindak, ${ }^{105}$ karena menjadi "tawanan" pembantu-pembantunya atau menjadi tawanan musuh. ${ }^{106}$ Jika kepala negara yang fasik kembali bersikap adil menurut al-Mawardi, maka ia tidak boleh melaksanakan jabatannya kecuali dengan kontrak sosial yang baru. ${ }^{107}$ Artinya kepala negara yang fasiq harus disingkirkan dan tidak lagi sah untuk menduduki jabatan itu. Jika kepala negara berada dalam tawanan, maka rakyat atau abl al-Ikhtiyar memilih orang lain yang mempunyai kekuatan. ${ }^{108}$

Dengan demikian, dapat dipahami bahwa Imam al-Haramain dan ulama-ulama Sunni yang lain, pada prinsipnya mereka tidak mengenal adanya suksesi (pemberhentian kepala negara). Namun, mereka juga menerima suksesi selama kepala negara masih hidup. Jika terdapat indikasi yang menunjukkan bahwa kepala negara harus

${ }^{104}$ Ibid., hlm. 8.

105Ibid., hlm. 17.

106Ibid., hlm. 20

${ }^{107}$ Ibid., hlm. 17.

${ }^{108}$ Ibid., hlm. 20 
Al-Fikra: Jurnal Ilmiah Keislaman, Vol. 7, No. 2, Juli-Desember 2008

dipecat dari jabatannya sebagai kepala negara. Terhadap alasan pemecatan kepala negara ulama Sunni dalam hal ini berbeda pendapat. Namun demikian, jika diperhatikan alasan-alasan mereka, sebenarnya tidak ada perbedaannya, secara substansi, menurut mereka, terjadinya suksesi itu apabila seorang kepala negara sudah tidak lagi melaksanakan syari'at Islam (fasiq dan fajir) dan tidak mampu menjalankan roda pemerintahan.

\section{Kesimpulan}

Pemikiran politik imam Haramain banyak berseberangan dengan pemikir politik sunni lainnya. Hukum pembentukan lembaga pemerintahan (Imamah-khilafah), menurut Imam alHaramain wajib berdasarkan ijma', sedangkan menurut ulama sunni lainnya, berdasarkan ijma' dan ketetapan nash dan perintah wahyu. Proses terbentuknya lembaga pemerintahan (negara), cara pemilihan kepala negara dan pemberhentian kepala Negara, beliau menganut teori kontrak sosial. Artinya, sumber kekuasaan bagi Imam al-Haramain berasal dari masyarakat. Persyaratan kepala Negara sebagai berikut : Pertama, seorang mujtahid. Kedua, mampu mengurus kemaslahatan dan memeliharanya dengan baik. Ketiga, punya kelebihan dalam mengatur militer dan mempertahankan pertahanan. Keempat, memiliki wawasan luas untuk memikirkan kepentingan kaum muslimin. Kelima, memiliki sifat lemah lembut. Keenam, menegakkan hukum bagi pelanggar hokum, dan ketujuh, Lakilaki muslim yang merdeka. Mekanisme pengangkatan kepala negara, Imam al-Haramain dalam hal ini menentukan melalui jalan proses pemilihan (al-Ikhtiyar) yang dilakukan oleh abl al-halli wa al-'aqd (wakil rakyat). Mekanisme pemberhentian kepala negara tidak mengenal adanya pembatasan jabatan kepala Negara selama kepala negara masih hidup dan tidak ada suksesi. Suksesi akan berlangsung setelah ia wafat. Suksesi bisa dipercepat pada waktu kepala negara masih hidup apabila ada suatu peristiwa atau perubahan dalam diri kepala negara yang membolehkan untuk suksesi, seperti apabila kepala negara fasiq dan fajir (melakukan perbuatan dosa dan tidak berlaku adil).
Irfan Zulfikar, Konfigurasi Pemikiran Politik. Islam Imam al-Haramain Bibliografi

Al-Baqillani, Nushush al-Fiker al-Siyasi al-Islami, Tahqiq Yusuf Ibish, (Beirut: ttp. 1966).

Al-Dib, Abd al-'Azim, Imam al-Haramain, (Kuwait: Dar al-Qalam, 1981).

Al-Ghazali, Al-Iqtishad fi al-I'tiqad, (Mesir: Maktabat al-Jund, 1972).

Al-Ghazali, Al-Munqiz, min al-Dhalalat, (Mesir: Maktabat al-Jund, 1961).

Al-Ghazali, Al-Musthashfa min Ilm al-Ushul, (Kairo: Maktabat alNahdhat al-Mishriyat, 1979).

Al-Ghazali, Al-Tibr al-Masbuk, fi Nasibat al-Mulk, (Kairo: tp., 1317 H.).

Al-Ghazali, Fadhaih al-Bathiniyah, (Kairo: tp., 1964).

Al-Ghazali, Ibya' 'Ulum al-Din, (Beirut: Dar al-Fikr, 1975).

Al-Ghazali, Kimya-i Sa'adat, Jilid I, (Teheran: ttp, 1940).

Al-Hadid, Ibn Abi, Syarh Nabj al-Balaghat, I (ed) Muhammad Abu Fahdl Ibrahim, (Kairo: ttp., 1959).

Al-Haramain, Imam, Al-Ghiyatsi Ghiyats al-Umam fi Tiyats al-Zhulam, Tahqiq Abdul al-Ashim al-Dayb, I, (Qathar: al-Syuun alDinayat, 1400).

Al-Haramain, Imam, Al-Irsyad ila Qawathi'i al-'Adillat fi Ushul al-I'tiqad, Tahqiq Muhammad Yusuf Musa dan 'Ali Abd al-Mun'im Abd al-Hamid, (Mesir: Maktabah al-Khaniji, 1959).

Al-Haramain, Imam, Lam'u al-'Adillat fi Qawa'id Abl al-Sunnah wa al Jama'ah, Tahqiq Fauqiyah Husain Mahmud, Tahqiq ulang Mahmud al-Khudairiy, (Kairo: Dar al-Mishriyyat, 1965)

Al-Jabbar, Abd, Al-Mughni fi Abwab al-Taubid wa al-'Adl, (Kairo: Dar al-Mishriyyat li al-Ta'lif wa al-Tarjamat, 1965).

Al-Jabbar, Abd, Syarh al-Ushul al-Khamsat, (Kairo: Maktabat Wahbat, 1965). 
Al-Fikra: Jurnal Ilmiah Keislaman, Vol. 7, No. 2, Juli-Desember 2008

Al-Maududi, Abu A'la, Islamic Law and Constitution, (Karachi: Islamic Publications LTD, 1960).

Al-Mawardi, Al-Abkam al-Sulthaniyat, (Beirut: Dar al-Fikr, tt.)

Al-Munifi, Abdullah A., The Islamic Constitusional Theory”, (Disertasi Doktor yang tidak dipublikasikan, Universitas Virginia, 1973).

Al-Rayis, Muhammad Dhiya' al-Din, Al-Nazhariyat al-Siyasat alIslamiyat, (Mishr: Maktabat al-Anlu, 1957).

Arnold, Thomas W., The Caliphate, (London: Routledge and Kegan Paul LTD., 1965).

Budiarjo, Miriam, Dasar-Dasar Ilmu Politik, (Jakarta: Gramedia Pustaka Utama, 1999).

Dahlan, Abdul Aziz, dkk., Ensiklopedi Hukum Islam, Jilid III, (Jakarta: Ichtiar Baru van Hoeve, 1996).

Daud, Abu, Sunan Abu Daud, Jilid III, (Beirut: Dar al-Fikr, 1988).

Duverger, Maurice, Sociologi Politik, (Jakarta: Rajawali, 1985).

Gibb, H.A.R., Muhammadanism An Historical Survey, (London: Oxford University Press, 1949).

Hanbal, Ahmad ibn, Al-Musnad, Jilid IV, (Beirut: Dar al-Fikr, tth.)

Hasan, Masudul, Reconstruktion of Political Thought in Islam, (Pakistan: Islamic Publication (Pvt) Ltd., 1988).

Houstma, M.TH., First Encyclopaedia of Islam, Jilid II, (Leiden: E.J. Brill, 1987).

Isywara, F., Pengantar Ilmu Politik, (Bandung: Angkasa, 1982).

Johan, Sudirman M., Politik Keagamaan Dalam Islam (Studi tentang Teori Imamat Mu'tazilat Menurut Konsepsi Abd al-Jabbar serta Perbandingannya dengan Teori Imamat Sunni dan Syiab), (Pekanbaru: Susqa Press, 1995).

Khaldun, Ibn, Muqaddimat, (Beirut: Dar al-Fikr, tt.).
Irfan Zulfikar, Konfigurasi Pemikiran Politik. Islam Imam al-Haramain

Khan, Qomaruddin, The Political Thought of Ibn Taimiyah, (Islamabad: Islamic Research Institute, 1973).

Lambton, Ann K.S., State and Government in Medieval Islam, (London: Oxford University Press, 1981)

Ma'arif, Ahmad Syafi'i, Islam dan Masalab Kenegaraan, (Jakarta: LP3ES, 1985).

Manzooruddin, Ahmed, The Classical Muslim State”, Islamic Studies I, (1962)

Metode Kritik Akal Islam : Wawancara dengan Mohammed Arkoun, Ulumul Qur'an, No. 5 dan 6, Vol. V. Th. 1994,

Muhajir, Noeng, Metodologi Penelitian Kualitatif, (Yogyakarta: Rake Sarasin, 1996)

Musa, Muhammad Yusuf, Nizham al-Hukm fi al-Islam, (Kairo: Dar alKitab al-'Arabi, 1963).

Noer, Deliar, Pemikiran Politik di Negara Barat, (Jakarta: Rajawali, 1982).

Poerwadarminta, W.J.S., Kamus Umum Bahasa Indonesia, (Jakarta: Balai Pustaka, 1983).

Rabi', Ibn Abi, Suluk al-Malik fi Tadbir al-Mamalik, (Kairo: Dar alSya'ab, 1970).

Redaksi, Dewan, Ensiklopedi Islam, Jilid II, Jakarta: Ichtiar Baru van Hoeve, 1994).

RI, Depag., Al-Qur'an dan Terjemahnya, (Surabaya: Mahkota, 1989).

Rosenthal, E.I.J., Political Thought ini Medieval Islam, (London: Cambridge University Press, 1962).

Sabaruddin TK. dan Krenenburg, Ilmu Negara Umum, (Jakarta: Pradya Paramita, 1986).

Sabine, George, A History of Political Theory, (Hindsale: Dryden Press, 1973). 
A1-Fikra: Jurnal Ilmiah Keislaman, Vol. 7, No. 2, Juli-Desember 2008

Shirwan, Harun Khan, Studies in Muslim Political Thought and Administration, (New Delhi: Heyderabad, 1945).

Strothmann, R., Mohammaed Prophet and Statement, (London: Oxford University, 1961).

Syamsuddin, M. Din, Etika Agama dalam membangun Masyarakat Madani, (Jakarta: Logos, 2000).

Syaraf, Muhammad Jalal dan Ali Abd al-Mu'thi Muhammad, Al-Fikr al-Siyasi fi al-Islam, (Iskandariyat: Dar al-Ma'rifat, 1987).

Taimiyah, Ibn, Al-Siyasat al-Syar'iyyat fi Ishlah al-Ra'iy wa al-Ra'iyyat, (Beirut: Dar al-Kutub al-'Arabiyat, 1966).

Taimiyah, Ibn, Majmu' al-Rasail al-Kubra, (Kairo: Mathba'at alAmiriyyat, $1323 \mathrm{H}$ ). 